WIDER Working Paper 2016/100

\title{
Human capital inequality and electoral outcomes in South Africa
}

Biniam Bedasso ${ }^{1}$ and Nonso Obikili ${ }^{2}$

September 2016 
Abstract: This paper examines the nature and evolution of horizontal and vertical human-capital inequality in South Africa since the end of apartheid. Using census data from 1996, 2001, and 2011, we use different measures of years of schooling to examine the dynamics both across and within racial, linguistic, gender, and geographic groups. We find that on average inequality has been falling in South Africa although with significant variation across the country. Finally we examine the relationship between changing inequality over time and electoral outcomes. We find that vertical inequality amongst youth is very strongly associated with changing electoral outcomes.

Keywords: inequality, political competition, voting behaviour, South Africa JEL classification: I24, D63, D72

Tables and Figures: at the end of the paper

Acknowledgements: The authors are thankful to DataFirst (https://www.datafirst.uct.ac.za) at the University of Cape Town for help with the data.

\footnotetext{
${ }^{1}$ Economic Research Southern Africa, Cape Town, South Africa and Princeton University, United States; ${ }^{2}$ Economic Research Southern Africa, Cape Town, South Africa and Stellenbosch University, South Africa, corresponding author: nonso.obikili@econrsa.org.
}

This study has been prepared within the UNU-WIDER project on 'Group-based inequality: patterns and trends within and across countries', which is part of a larger research project on 'Disadvantaged groups and social mobility'.

Copyright (C) UNU-WIDER 2016

Information and requests: publications@wider.unu.edu

ISSN 1798-7237 ISBN 978-92-9256-144-4

Typescript prepared by Lesley Ellen.

The United Nations University World Institute for Development Economics Research provides economic analysis and policy advice with the aim of promoting sustainable and equitable development. The Institute began operations in 1985 in Helsinki, Finland, as the first research and training centre of the United Nations University. Today it is a unique blend of think tank, research institute, and UN agency — providing a range of services from policy advice to governments as well as freely available original research.

The Institute is funded through income from an endowment fund with additional contributions to its work programme from Denmark, Finland, Sweden, and the United Kingdom.

Katajanokanlaituri 6 B, 00160 Helsinki, Finland

The views expressed in this paper are those of the author(s), and do not necessarily reflect the views of the Institute or the United Nations University, nor the programme/project donors. 


\section{Introduction}

Inequality is a problem which has beset South Africa for a long time with the country being on record as having one of the highest levels of inequality in the world. However, little is known about horizontal inequality between different groups in South Africa. Given the level of racial and ethnic diversity in South Africa, it is important to have a good grasp of the dynamics of group inequality in the country.

In this paper we use data from the censuses of 1996, 2001, and 2011 in South Africa to compute different measures of horizontal inequality. For reasons of data availability, we focus on human capital inequality. We find varying levels of horizontal inequality in schooling depending on how groups are defined. Horizontal inequality also varies across municipalities. On average we do find that horizontal inequality has been falling over time.

We extend the study by examining the relationship between horizontal and vertical inequality and electoral outcomes. We find that horizontal inequality when individuals are grouped by language is sometimes associated with higher levels of electoral competition. This implies that socioeconomic differences among the majority black population may have a bigger impact on electoral competition than similar differences between the races. However, vertical inequality in schooling between individuals younger than 15 years of age is strongly associated with lower levels of electoral competition. Considering the high prob-

ability that the schooling of young people mirrors the incomes of their parents, this result seems to suggest that municipalities which are stratified along class lines see less competition electorally.

This paper contributes to the literature on horizontal inequality within countries. By taking South Africa as a case, it sheds light on the dynamic of inequality in a post-transition society. It also contributes to the literature on the impacts of horizontal and vertical inequality, and the determinants of political and electoral competition.

The paper proceeds as follows. Section 2 provides a brief overview of inequality in South Africa. Section 3 discusses the data used. Section 4 discusses the patterns and trends 
of horizontal inequality in South Africa. Section 5 gives a summary of vertical inequality in South Africa based on the dataset and outcome variables used. Section 6 explores the relationship between horizontal and vertical inequality and electoral outcomes. Section 7 concludes.

\section{Background and literature review}

South Africa has a population of 51.8 million as of the 2011 census. The portion of the population living under the poverty line of 620 South African rands stands at 45.2 percent in 2011. Although headcount poverty has declined significantly in recent years, down from 57.2 percent in 2006, a substantial portion of the population remains vulnerable to shocks. This is demonstrated by the 2.2 million increase in the number of South Africans living under the food poverty line in 2009 around the time of the financial crisis. South Africa continues to be one of the most unequal nations in the world with a Gini coefficient of income of 0.69 in 2011. Adults in the top 1 percent of the income distribution earn around 16.6 percent of income (Alvaredo et al., 2016).

The most salient social cleavage that has shaped the history of the South African nation is racial division. According to the official classification, the country is composed of four major racial groups: black African (79.2 per cent), white (8.9 per cent), coloured (8.9 per cent), and Indian or Asian (2.5 per cent). South Africa is also a multi-ethnic society. The black African part of the population is composed of nine official language groups. The ethnic fractionalization and ethnic polarization indexes of the country are given as 0.47 and 0.72 , indicating that South Africa is not as ethnically fragmented as numerically polarized (Montalvo and Reynal-Querol, 2005). Due to the history of the nation that involves a period of apartheid, the most significant dimension of group inequality is race. As at 2011, 54 percent of black South Africans live under the national poverty line whereas the corresponding figure for white South Africans is 0.8 percent. Although it is not as pronounced as the racial 
divide, there is sizable regional disparity in the incidence of poverty. The poverty rate in the least deprived province, Limpopo, is almost three times higher than the poverty rate in the wealthiest province, Gauteng.

Historically, horizontal inequalities in South Africa were the product of legalized discrimination enforced as part of apartheid. "Black people and white people with the same qualifications were paid different wages for performing the same job, especially in the public sector" (Nattrass and Seekings, 2005, p. 2). Hence, racial inequality remains the most politically salient aspect of income inequality in South Africa. Since much of South Africa's labour force has been urbanized, a large part of income inequality is accounted for by wage inequality. Racial wage inequality persists even after systematic discrimination was removed with political liberalization in the mid-1990s. The differences in years of schooling between white groups and other groups explains almost half of the remaining wage inequality (Mwabu and Schultz, 2000). In general, the high incidence of poverty among black Africans in the post-apartheid period can be attributed to the accumulation of mainly pre-labour market disadvantages (Gradin, 2015). According to Gradin (2015), quality of education as well as quantity of schooling seems to put blacks at a disadvantage judging from the rise in the importance of unobservables in explaining poverty differentials by race.

As apartheid wound down, racial inequality began declining. Seekings and Nattrass (2005) argue that, in the final years of apartheid, "upward occupational mobility among black workers, and rising unemployment resulted in declining interracial inequality but rising intraracial inequality, especially among the black population" (Seekings and Nattrass 2005, p. 47). The decline in the relevance of between-group inequality in the first decade following the end of apartheid can be attributed mostly to the increase in inequality among black Africans rather than to the diminishing of racial inequality as such (Özler, 2007). In relation to within-black inequality, Gradin (2015) demonstrates the importance of the gap in poverty levels between the Xhosa and the Zulu on one hand, and the Sotho and Tswana on the other. He argues that education, as well as location, demographic structure, and labour 
market outcomes, is associated with these differences.

De facto segregation of different races across the urban landscape also contributes to the persistence of group inequalities. Schensul and Heller (2011) studied the case of Durban to highlight the dynamics of spatial inequality since the fall of apartheid. They found that the rate of unemployment in African townships in 2001 was 59.6 percent compared to 7.8 percent in predominantly white areas. Past group inequalities that are still embodied by spatial segregation may perpetuate themselves through the type of human capital young people acquire which is strongly influenced by near-peer influence (Bedasso, 2015). But it is not only where South Africans live that may contribute to the persistence of group inequality. It is also who they were born to that determines their chances in life (Magruder, 2010). Whether it is through familial network or endowment, young people who hail from groups that have done well in the past are likely to continue doing relatively well in the

present. Piraino (2015) argues that inherited circumstances explain a significant fraction of South Africa's earnings inequality.

\section{Data}

\subsection{Characteristics of the population}

This paper uses census data collected by Statistics South Africa. Census data for three years, 1996, 2001, and 2011, has been made available thanks to DataFirst. Although the entire census has not been made available, a 10 percent sample is used. This sample includes information for about 3.6 million people in 1996, 3.7 million people in 2001, and 4.4 million people in 2011.

We categorize individuals into groups based on four different specifications. Firstly, individuals are grouped based on race which all three censuses report. Individuals indicate if they are black African, coloured, Indian or Asian, white, or other. Horizontal inequality measures are calculated based on the reported racial categories. 
Although inequality measures based on the race-based grouping are important, this could potentially hide group dynamics within races. For example, individuals identified as black may be of different ethnic backgrounds. Likewise, individuals identified as white may also be of different ethnic backgrounds. Although strict ethnicity data is not collected in the census, data about the first language is collected. We therefore calculated horizontal inequality based on the reported language as our second group-based measure. Individuals are grouped based on 11 official language categories; Afrikaans, English, IsiNdebele, IsiXhosa, IsiZulu, Sepedi, Sesotho, Setswana, SiSwati, Tshivenda, and Xitsonga. Most of the groups, the exceptions being Afrikaans and English, are dominated by black Africans.

A couple of other unofficial languages, such as German and Portuguese, are occasionally reported. These extra language groups are omitted because they represent an insignificant fraction of the sample. For instance, respondents who listed Portuguese as their first language only accounted for 0.08 percent of individuals in the 1996 census. The sign-language category is also omitted for similar reasons.

Inequality between genders is an important feature in many countries. We therefore calculate horizontal inequality for gender to examine gender-based inequality in South Africa. Finally, we calculate horizontal inequality based on rural-urban settlements.

The distribution of the population in each of the groups and for all the years under observation is reported in Table 1.

\subsection{Schooling in South Africa}

Inequality in this paper is measured using years of schooling. The South African schooling system is modelled after the British schooling system with some differences. The schooling system can be grouped in three broad categories: general education, further education, and higher education. General education typically runs for 10 years, from grade zero to grade nine. Further education, which involves more career-focused learning, typically lasts for three years, from grades 10 to 13, after which students matriculate. Matriculation in South 
Africa is equivalent to finishing secondary education in other countries. Further education also includes some diplomas and technical training. Finally, higher education is as in other countries and involves university degrees and others.

In the context of this paper schooling is measured in three ways. First we calculate years of schooling for individuals above the age of 15 , secondly we calculate years of schooling for individuals above the age of 25 , and finally we calculate years of schooling for individuals below the age of 15 . We use these measures to capture generational differences in schooling between groups.

Table 2 shows the distribution of average years of schooling for individuals aged 15 and above. Table 3 shows the distribution for individuals aged 25 and above. Finally, Table 4 shows the distribution for individuals less than 15 years old. On average the years of schooling by all measures appear to be increasing over time. This suggests that South Africans are, on average, spending more time in school. Tables 2 to 4 also show the distributions of schooling for all the distinct groups being considered. From a racial perspective, there are significant differences between the groups. The white group has the highest average followed by the Asian/Indian group and then the coloured and black groups. Although the spread between the groups has declined over time, the differences are still apparent.

Similar patterns are clear when individuals are grouped according to linguistic groups. The English and Afrikaans groups have more years of schooling on average than the other groups although the spread has decreased over time. Individuals in urban areas tend to have more schooling than those in rural areas, which is not unexpected. Finally, there does not appear to be any large difference between genders although males on average have more years of schooling than females.

In this paper inequality is computed at the national and municipal levels. However, the names, and in some instances boundaries, of municipalities have changed between 1996 and 2001, and between 2001 and 2011. This poses a challenge when trying to compare municipallevel changes in inequality over time. To get around this problem, individuals are mapped 
based only on the 2011 municipalities. This remapping results in some instances where early municipalities cannot be mapped. Municipalities that were split in half for instance cannot be mapped because the specific location of individuals is not reported. The remapping results in three of 234 municipalities being dropped in 2001, and 28 of 234 municipalities being dropped in 1996. Specific details of mappings and early municipalities that could not be mapped are explained in the Appendix A.1.

\section{Horizontal inequality}

\subsection{Patterns and trends}

This paper uses five different measures of group-based horizontal inequality. We use the group-weighted coefficient of variance (GCOV), the group-weighted Gini coefficient (GGini), and the group-weighted Theil (GTheil) as used in Stewart et al., (2010). We also calculate crosscuttingness and crossfractionalization as used in Selway (2011). Tables 5 to 7 report the horizontal inequalities for the three different measures of schooling.

Some patterns show up across all three measures of schooling. First, when individuals are grouped according to race, horizontal inequality appears to be falling consistently across all schooling measures. The exception to this is crosscuttingness for grouped individuals below the age of 15 where it falls between 1996 and 2001 and then increases a bit by 2011 but is still far below the 1996 measure. Horizontal inequality, when individuals are grouped according to linguistic group, is a bit mixed. Crosscuttingness and crossfractionalization appear to be almost fixed throughout the period under observation with neither measure rising nor falling significantly. The GGini and GTheil measures show a continuous reduction in horizontal inequality over the period. The GCOV shows a big increase between 1996 and 2001 and then a subsequent drop by 2011. In essence the measures all tell different stories about the evolution of horizontal inequality by linguistic group over time.

Horizontal inequality by gender appears to be very low across all measures. The GTheil, 
crossfractionalization, and crosscuttingness show almost no change in horizontal inequality between males and females. The GCOV and GGini show low levels of horizontal inequality but even those appear to be falling over time.

Finally, the data shows relatively high levels of horizontal inequality between urban and rural groups. It shows that horizontal inequality between urban and rural groups has only fallen a little since 1996.

\subsection{Comparison of measures}

The large sample size allows us to compute horizontal inequality measures for municipalities in South Africa. Computing horizontal inequality at that level allows us to compare the different measures and how well they correlate with each other.

The GCOV, Ggini, and GTheil measures all appear to be very highly correlated. The crosscuttingness and crossfractionalization measures also appear to be strongly correlated. However, the correlation between the GCOV, GGini, and GTheil group and the crosscuttingness and crossfractionalization group is mostly weak.

Figure 1 shows a scatterplot of GCOV and GGini for municipalities in 2011 using years of schooling above the age of 15 and grouped by race. As is clear, the majority of the data points show a very strong correlation across the two measures. However, there are significant numbers of cases where the correlations do not match up. Figure 2 compares the GGini and the GTheil using the same schooling variable and grouping. The same broad correlation is clear although they are not perfectly correlated.

Figure 3 shows a scatterplot of crosscuttingness and crossfractionalization for municipalities using years of schooling and grouped by race. Both measures appear to be very strongly correlated. Finally Figure 4 shows a scatterplot of crosscuttingness and GGini using the same groupings. In this case there appears to be only a weak correlation between the two.

The same patterns are apparent using other measures of schooling and the different schooling categories. Due to space constraints they are not included. In general, the cross- 
cuttingness and crossfractionalization measures broadly match while the GCOV, GGini, and GTheil measures match up too. The two groups, however, are not always correlated.

\subsection{Spatial variation and the importance of group definition}

The calculations of horizontal inequality at the municipal level also allow us to examine the spatial distribution across the country and how this has changed over time. Figure 5 shows the distribution of GCOV using years of schooling for individuals 15 years of age and older, and grouped by race. Panel (a) measures this in 1996, (b) in 2001, and (c) in 2011. Two things are apparent from the map. First, horizontal inequality varies across municipalities. Second, there has been a fall in horizontal inequality on average. However, the fall is not universal as there are municipalities where horizontal inequality has increased. Panel (d) shows the distribution of the change in GCOV with red areas showing an increase between 1996 and 2011 and blue areas showing a decrease. The municipalities where horizontal inequality has increased appear to mostly be located in the eastern parts of the country.

Figure 6 repeats the mapping in Figure 5 but in this case individuals are grouped according to language. Similar patterns are visible. There is variation in horizontal inequality across municipalities although on average it has been falling over time. Again the change in horizontal inequality is not identical across municipalities. In some, it has decreased but it has increased in others. As shown in panel (d) a significant cluster of municipalities in the western part of the country show an increase in horizontal inequality between 1996 and 2011. This is markedly different to the case where individuals are grouped by race. This distinction is particularly important given that some studies (Stanfield, 1993; Neff, 2007) argue that ethnicity-based measures provide more insight into inequality than race-based measures. The spatial difference between the race and language measures highlights the importance of thinking through group definitions and understanding the context in which inequality is discussed.

Figure 7 shows the same distributions with individuals grouped according to gender and 
Figure 8 shows horizontal inequality with individuals grouped by rural or urban location. Almost all municipalities show significantly low levels of horizontal inequality when grouped by gender although there are exceptions. There is also a diverse distribution of municipalities where horizontal inequality has increased or decreased. Horizontal inequality is present when individuals are grouped by rural or urban location. Although it is falling on average, there are municipalities showing an increase in horizontal inequality between 1996 and 2011.

The spatial distributions highlight the importance of group definitions when measuring horizontal inequality. When measured by race, the data suggests that horizontal inequality is higher in the western parts of the country. However, when measured by language, the data suggests that horizontal inequality is higher in the eastern parts of the country. The same scenarios appear when looking at the change in inequality and when individuals are grouped by gender or rural/urban locations.

\section{Within-group vertical inequality: trends}

The horizontal inequality measures help us understand inequality between the average members of different groups. However, it might also be useful to understand the dynamics within the different groups and how these have changed over time. First we calculate vertical inequality for all of South Africa using all three measures of years of schooling. The calculations are reported in Table 8. Vertical inequality appears to be high using all three measures. It has, however, been falling consistently across all years using almost all measures. The exception is vertical inequality for individuals younger than 15 years old where it rises between 1996 and 2001 and then falls by 2011.

Table 9 shows the vertical inequality measures within groups for individuals 15 years of age and older. Some interesting observations stand out. First, inequality is higher within the black African groups compared to the others. This is true whether looking at the race groups, in which case the black group is characterized by significantly higher inequality, or the 
language groups, in which case the black languages have significantly higher levels of vertical inequality. On the flip side, inequality within the white race group appears to be relatively low. This is also true for inequality within the English-speaking and to some extent the Afrikaans-speaking, groups. This finding is consistent with the work of van der Berg (2007) who finds lower pass rates and relatively higher standard deviations in pass rates for black schools in South Africa. This of course implies that a relatively small fraction of people attending black schools get quality education but the average is much lower than other non-black schools. This characteristic should result in higher inequality within the black schools which is what we find here. The distribution of vertical inequality for individuals older than 25 years and younger than 15 are shown in Tables A2.1 and A2.2 of the Appendix respectively. In general, the same patterns are present.

Vertical inequality within the male and female groups appears to be almost identical. Finally, inequality between urban residents appears to be much lower than inequality between rural residents.

In general, the computations show varying degrees of vertical inequality within the various groups.

\section{Inequality and political action}

\subsection{Background}

Many economists have suggested that inequalities have long-term consequences on various development outcomes. Although the reduction of inequality is considered an outcome of development itself, high levels of inequality can have varying economic and socio-political effects.

With regards to vertical inequality, some papers have argued and found various relationships between inequality and politics. For instance, Solt (2010) finds that in the United States, states with greater income inequality are less likely to vote. Ziblatt (2008) also finds 
that land inequality in Prussia impeded early democratization. The argument in many cases is that in societies with high levels of inequality, groups at the top of the spectrum have greater incentives to monopolize political power (Boix, 2003). Therefore, higher inequality will be associated with less competitive electoral outcomes.

Horizontal inequality is also thought to have some effects on its own. Many early studies argued that horizontal inequality, specifically crosscutting measures, was an important factor in voting behaviour (Dahl, 1956), political organization (Lazarsfeld et al., 1968), and democratic stability (Lipset, 1960). More recently Gubler and Selway (2012) argue that civil wars are less likely to occur in societies with high levels of crosscuttingness. They argue that high levels of crosscuttingness make it more difficult to rally around any particular rebel leader.

Although the possibility of civil war in South Africa is very low, the same kind of dynamics could play out at the ballot box. However, instead of rebel leaders, political parties are the groups which try to dethrone leading parties. They have to mobilize enough support to overthrow the leading party. Is it the case, as with civil wars, that high crosscuttingness makes building such support more difficult?

In this paper we jointly test the effects of both vertical and horizontal inequality on electoral outcomes. We examine whether it is the case that voters in municipalities with high levels of inequality punish leading political parties. We also test whether punishing political parties is more difficult in municipalities with higher horizontal inequality.

\subsection{Data and model specification}

We specify a simple electoral outcomes equation to measure the effects of vertical and horizontal inequality in educational attainment.

$$
E_{i t}=\beta_{1} V_{i t}+\beta_{2} H_{i t}+\beta_{3} X_{i t}+\alpha_{i}+u_{i t}
$$


The dependent variable, $E_{i t}$, represents one of the two indicators of electoral outcomes for district I in year t. $V_{i t}$ represents a measure of vertical inequality in schooling, specifically the Gini coefficient. $H_{i t}$ stands for one of the alternative measures of horizontal inequality in schooling. $X_{i t}$ is a vector of control variables including the level of poverty in the district and the provision of public goods in district. $\alpha_{i}$ captures the district fixed effects and $u_{i t}$ is the error term.

Data on electoral outcomes is taken from results at the national elections of 1994, 1999, and 2009. We use two measures of electoral outcomes. First, we use the share of votes of the winning party in each municipality. In this context we want to examine if changing inequality is associated with a changing share of the winning party. Secondly we use winning margin between the top two political parties in that municipality. This variable in effect measures how voters switch between the top two parties.

In order to construct a panel from the available data, we need to conjoin census data from one year with elections data from another year to form a single data point representing a given period. Therefore, we have determined a single data point to span two years in which a general election is held and census data is collected. Accordingly, the first data point, $\mathrm{t}=1$, represents the period 1994 and 1996, bundling together the census in 1996 and the elections in 1994 as observations in the same era. Likewise, the second data point, $\mathrm{t}=2$, represents the periods between 1999 and 2001. Finally, the third data point, t=3, represents the periods between 2009 and 2011.

\subsection{Results}

We estimate our model using all three measures of schooling. Abridged results are shown in Tables 10 to 16. Full results are available in Tables A3.1 to A3.6 in the Appendix. The results from our regressions are somewhat mixed and support the claim we made that the way in which groups are defined when discussing horizontal inequality is important. Only language-based horizontal inequality appears to be correlated with electoral outcomes. 
Our results show that, in some cases, increases in horizontal inequality are associated with lower winning shares of the ruling party and lower winning margins. These results are particularly persistent when horizontal inequality is measured by GGini. The results are, however, inconsistent with Gubler and Selway (2012) in the sense that higher inequality does not entrench the already leading party, but seems to make it more difficult for the leading party to be completely dominant or maintain its dominant position. In essence, municipalities with higher horizontal inequality appear to have more competitive electoral outcomes.

The results on vertical inequality are also somewhat interesting. First, vertical inequality for adults, i.e. individuals older than 15 years of age, appears not to be correlated with electoral outcomes. However, youth inequality, i.e. inequality between individuals younger than 15 years of age, appears to be strongly correlated with electoral outcomes. Municipalities with higher levels of vertical inequality appear to be the least competitive electorally. This relationship is present and significant at the 1 percent level when either the share won by the winning party or the winning margin is used. The result is consistent with the arguments made by Boix and Stokes (2003) and Ziblatt (2008). Political power, measured in this paper by the dominance of specific political parties, is less competitive in municipalities with high inequality.

\section{Conclusion}

This paper explores the patterns and trends of group-based inequalities in South Africa. We use data from the census of South Africa in 1996, 2001, and 2011 to compute various inequality measures. Using different measures of schooling we compute five different measures of group-based inequality for individuals grouped by race, language, gender, and rural or urban location. We find significant levels of horizontal inequality in South Africa although with a decent amount of variation across municipalities. However, the extent of horizontal 
inequality depends greatly on how groups are defined. Race-based inequality appears to be relatively more prevalent in the western parts of the country. On the other hand, languagebased inequality appears to be more prevalent in eastern parts.

On average, inequalities appear to have reduced over time using any of the groupings and any of the schooling variables. This reduction is not present in all municipalities with some showing an increase in horizontal inequality. Gender-based inequality in South Africa does not seem to be significant.

We extend the study to examine the relationship between horizontal and vertical inequality on electoral outcomes. Using corresponding data from elections in South Africa we find that horizontal inequality is positively correlated with electoral competition. Municipalities with higher levels of horizontal inequality tend to be more competitive electorally, although this relationship is only present when individuals are grouped by language. We also find that vertical inequality between individuals below 15 years old is strongly associated with lower electoral competition. Municipalities with high levels of vertical inequality tend to be dominated by single parties and hold elections with wide winning margins and poor opposition outcomes.

This paper contributes to the literature on horizontal and vertical inequality within countries. It also opens up the potential for interesting research on the relationships between inequality and political outcomes.

\section{References}

Alvaredo, F., Atkinson, T., Piketty, T., Saez, E., and Zucman, G. (2016). The World Wealth and Income Database. Available at http://www.wid.world/

Bedasso, B. B. (2015). College Major Choice, Spatial Inequality and Elite Formation: Evidence from South Africa. Economic Research Southern Africa Working Paper Series, No. 552. 
Boix, C. and Stokes S. C. (2003). Endogenous Democratization. World Politics, 55(4), $517-549$.

Dahl, R. (1956). A Preface to Democratic Theory. Chicago University Press: Chicago.

Gubler, J. R. and Selway J. S. (2012). Horizontal Inequality, Crosscutting Cleavages, and Civil War. Journal of Conflict Resolution, 56(2), 206-232.

Gradin, C. (2015). Poverty and Ethnicity among Black South Africans. The European Journal of Development Research, 27(5), 921-924.

Lazarsfeld, P. F., Berelson, B., and Gaudet, H. (1968). The People's Choice: How the Voter Makes up His Mind in a Presidential Campaign. Columbia University Press: New York.

Lipset, S. (1960). Political Man. Johns Hopkins Press: Baltimore.

Magruder, J. R. (2010). Intergenerational Networks, Unemployment, and Persistent Inequality in South Africa. American Economic Journal: Applied Economics, 2(1), 62-85.

Montalvo, J. G., and Reynal-Querol, M. (2005). Ethnic Polarization, Potential Conflict and Civil War. American Economic Review, 95(3), 796-816.

Mwabu, G., and Schultz, T. P. (2000). Wage Premiums for Education and Location of South African Workers, by Gender and Race. Economic Development and Cultural Change, 48(2), 307-334.

Nattrass, N. and Seekings, J. (2005). Class, Race and Inequality in South Africa. New Haven: Yale University.

Neff, F. D. (2007) Subjective Well-Being, Poverty and Ethnicity in South Africa: Insights from and Exploratory Analysis. Social Indicators Research, 80(2), 313-341.

Özler, B. (2007). Not Separate, Not Equal: Poverty and Inequality in Postapartheid South Africa. Economic Development and Cultural Change, 55(3), 487-529. 
Piraino, P. (2015). Intergenerational Earnings Mobility and Equality of Opportunity in South Africa. World Development, 67, 396-405.

Schensul, D., and Heller, P. (2011). Legacies, Change and Transformation in the Postapartheid City: Towards an Urban Sociological Cartography. International Journal of Urban and Regional Research, 35(1), 78-109.

Selway, J. S. (2011). The Measurement of Cross-cutting Cleavages and Other Multidimensional Cleavage Structures. Political Analysis, 19(1), 48-65.

Solt, F. (2010). Does Economic Inequality Depress Electoral Participation? Testing the Schattschneider Hypothesis. Political Behaviour, 32(2), 285-301.

Stanfield, J. H. (1993). Race and Ethnicity in Research Methods. Sage, London: London.

Stewart, F., Brown, G., and Mancini, L. (2010). Monitoring and Measuring Horizontal Inequalities. Centre for Research on Inequality, Human Security and Ethnicity, Oxford: Oxford.

van der Berg, S. (2007). Apartheid's Enduring Legacy: Inequalities in Education Journal of African Economies, 16(5), 849-880.

Ziblatt, D. (2008). Does Landholding Inequality Block Democratization? A Test of the "Bread and Democracy" Thesis and the Case of Prussia. World Politics, 60(4), 610-641. 


\section{Tables and Figures}

Table 1: Distribution of population

\begin{tabular}{ccccc}
\hline \hline \multirow{4}{*}{ Race } & & $\mathbf{1 9 9 6}$ & $\mathbf{2 0 0 1}$ & $\mathbf{2 0 1 1}$ \\
& Black & $73 \%$ & $76 \%$ & $77 \%$ \\
& Coloured & $9 \%$ & $9 \%$ & $9 \%$ \\
& Indian/Asian & $3 \%$ & $3 \%$ & $3 \%$ \\
& White & $14 \%$ & $11 \%$ & $10 \%$ \\
\hline \multirow{6}{*}{ Language } & IsiNdebele & $1 \%$ & $2 \%$ & $2 \%$ \\
& isiXhosa & $17 \%$ & $17 \%$ & $15 \%$ \\
& IsiZulu & $21 \%$ & $22 \%$ & $20 \%$ \\
& Sepedi & $8 \%$ & $9 \%$ & $9 \%$ \\
& Sesotho & $8 \%$ & $8 \%$ & $8 \%$ \\
& Setswana & $8 \%$ & $9 \%$ & $8 \%$ \\
& Siswati & $2 \%$ & $3 \%$ & $2 \%$ \\
& Tshivenda & $2 \%$ & $2 \%$ & $2 \%$ \\
& Xitsonga & $4 \%$ & $4 \%$ & $4 \%$ \\
& Afrikaans & $16 \%$ & $15 \%$ & $14 \%$ \\
& English & $10 \%$ & $10 \%$ & $10 \%$ \\
\hline \multirow{2}{*}{ Gender } & Female & $52 \%$ & $53 \%$ & $52 \%$ \\
& Maral $/$ Urban & $48 \%$ & $47 \%$ & $48 \%$ \\
\hline \multirow{2}{*}{ Run } & Urban & $54 \%$ & $57 \%$ & $63 \%$ \\
& Rural & $46 \%$ & $43 \%$ & $37 \%$ \\
\hline
\end{tabular}

Source: Authors' calculations. 
Table 2: Average years of schooling. 15+

\begin{tabular}{ccccc}
\hline \hline \multirow{4}{*}{ Race } & & $\mathbf{1 9 9 6}$ & $\mathbf{2 0 0 1}$ & $\mathbf{2 0 1 1}$ \\
\hline & Black & 6.6 & 7.1 & 8.9 \\
& Coloured & 7.9 & 8.3 & 9.3 \\
& Indian/Asian & 9.8 & 10.3 & 11.2 \\
& White & 11.8 & 12.0 & 12.7 \\
\hline & IsiNdebele & 6.3 & 6.8 & 8.8 \\
& isiXhosa & 6.5 & 6.9 & 8.6 \\
& IsiZulu & 6.5 & 7.1 & 8.9 \\
& Sepedi & 6.8 & 7.3 & 9.0 \\
& Sesotho & 7.0 & 7.6 & 9.1 \\
Language & Setswana & 6.8 & 7.4 & 8.9 \\
& Siswati & 6.1 & 6.8 & 8.7 \\
& Tshivenda & 6.7 & 7.4 & 9.2 \\
& Xitsonga & 6.0 & 6.5 & 8.3 \\
& Afrikaans & 9.5 & 9.5 & 10.4 \\
& English & 11.1 & 11.4 & 11.8 \\
\hline \multirow{2}{*}{ Gender } & Female & 7.4 & 7.7 & 9.3 \\
& Male & 7.7 & 8.1 & 9.5 \\
\hline \multirow{2}{*}{ Rural/Urban } & Urban & 8.8 & 9.0 & 10.2 \\
& Rural & 5.7 & 6.0 & 7.8 \\
\hline \multirow{6}{*}{ Soly } & & &
\end{tabular}

Source: Authors' calculations. 
Table 3: Average years of schooling. 25+

\begin{tabular}{ccccc}
\hline \hline \multirow{4}{*}{ Race } & & $\mathbf{1 9 9 6}$ & $\mathbf{2 0 0 1}$ & $\mathbf{2 0 1 1}$ \\
& Black & 5.9 & 6.4 & 8.5 \\
& Coloured & 7.5 & 7.9 & 9.1 \\
& Indian/Asian & 9.5 & 10.1 & 11.2 \\
& White & 12.0 & 12.2 & 12.9 \\
\hline \multirow{6}{*}{ Language } & IsiNdebele & 5.1 & 5.8 & 8.3 \\
& isiXhosa & 5.9 & 6.3 & 8.2 \\
& IsiZulu & 5.7 & 6.3 & 8.3 \\
& Sepedi & 5.7 & 6.4 & 8.5 \\
& Sesotho & 6.4 & 7.0 & 8.7 \\
& Setswana & 6.3 & 6.8 & 8.5 \\
& Siswati & 5.0 & 5.8 & 8.1 \\
& Tshivenda & 5.6 & 6.5 & 8.8 \\
& Xitsonga & 4.9 & 5.7 & 7.7 \\
& Afrikaans & 9.4 & 9.5 & 10.4 \\
& English & 11.1 & 11.5 & 12.0 \\
\hline \multirow{2}{*}{ Gender } & Female & 6.8 & 7.1 & 8.9 \\
& Male & 7.4 & 7.8 & 9.3 \\
\hline \multirow{2}{*}{ Rural/Urban } & Urban & 8.6 & 8.8 & 10.1 \\
& Rural & 4.7 & 5.0 & 6.9 \\
\hline
\end{tabular}

Source: Authors' calculations. 
Table 4: Average years of schooling. -15

\begin{tabular}{ccccc}
\hline \hline \multirow{4}{*}{ Race } & & $\mathbf{1 9 9 6}$ & $\mathbf{2 0 0 1}$ & $\mathbf{2 0 1 1}$ \\
& Black & 2.6 & 2.1 & 3.2 \\
& Coloured & 3.0 & 2.3 & 3.3 \\
& Indian/Asian & 3.9 & 2.7 & 3.7 \\
& White & 3.5 & 2.6 & 3.3 \\
\hline \multirow{6}{*}{ Language } & IsiNdebele & 3.0 & 2.1 & 3.2 \\
& isiXhosa & 2.2 & 1.9 & 3.0 \\
& IsiZulu & 2.7 & 2.1 & 3.3 \\
& Sepedi & 2.9 & 2.1 & 3.3 \\
& Sesotho & 2.7 & 2.1 & 3.2 \\
& Setswana & 2.7 & 2.0 & 3.1 \\
& Siswati & 2.6 & 2.0 & 3.3 \\
& Tshivenda & 2.8 & 2.2 & 3.4 \\
& Xitsonga & 2.8 & 2.1 & 3.2 \\
& Afrikaans & 3.1 & 2.3 & 3.3 \\
& English & 3.6 & 2.5 & 3.4 \\
\hline \multirow{2}{*}{ Gender } & Female & 2.9 & 2.2 & 3.3 \\
& Male & 2.6 & 2.0 & 3.2 \\
\hline \multirow{2}{*}{ Rural/Urban } & Urban & 3.0 & 2.2 & 3.3 \\
& Rural & 2.5 & 2.0 & 3.2 \\
\hline
\end{tabular}

Source: Authors' calculations. 
Table 5: Aggregate measures of horizontal inequality

\begin{tabular}{|c|c|c|c|c|c|}
\hline & Year & $\begin{array}{c}\text { Race } \\
(1)\end{array}$ & $\frac{\text { Language }}{(2)}$ & $\frac{\text { Gender }}{(3)}$ & $\frac{\text { Rural/Urban }}{(4)}$ \\
\hline \multicolumn{6}{|c|}{ A. Years of education $(15+)$} \\
\hline \multirow{4}{*}{ GCOV } & 1996 & 0.103 & 0.026 & 0.016 & 0.127 \\
\hline & 2001 & 0.083 & 0.047 & 0.017 & 0.111 \\
\hline & 2011 & 0.045 & 0.015 & 0.009 & 0.105 \\
\hline & $\Delta$ & - & - & - & - \\
\hline \multirow{4}{*}{ GGini } & 1996 & 0.039 & 0.083 & 0.005 & 0.051 \\
\hline & 2001 & 0.031 & 0.068 & 0.006 & 0.047 \\
\hline & 2011 & 0.017 & 0.035 & 0.003 & 0.030 \\
\hline & $\Delta$ & - & - & - & - \\
\hline \multirow{4}{*}{ GTheil } & 1996 & 0.025 & 0.021 & 0.000 & 0.021 \\
\hline & 2001 & 0.018 & 0.015 & 0.000 & 0.018 \\
\hline & 2011 & 0.007 & 0.006 & 0.000 & 0.008 \\
\hline & $\Delta$ & - & - & & - \\
\hline \multirow{2}{*}{ Cross- } & 1996 & 0.552 & 0.205 & 0.501 & 0.497 \\
\hline & 2001 & 0.585 & 0.206 & 0.502 & 0.507 \\
\hline \multirow{2}{*}{ fractionalization } & 2011 & 0.601 & 0.216 & 0.501 & 0.526 \\
\hline & $\Delta$ & + & + & & + \\
\hline \multirow{2}{*}{ Cross- } & 1996 & 0.731 & 0.885 & 0.291 & 0.284 \\
\hline & 2001 & 0.548 & 0.885 & 0.291 & 0.275 \\
\hline \multirow{2}{*}{ cuttingness } & 2011 & 0.603 & 0.898 & 0.292 & 0.258 \\
\hline & $\Delta$ & - & + & + & - \\
\hline
\end{tabular}

Source: Authors' calculations. $\Delta$ is change from 1996 to 2011 
Table 6: Aggregate measures of horizontal inequality

\begin{tabular}{|c|c|c|c|c|c|}
\hline & Year & Race & Language & Gender & Rural/Urban \\
\hline & & (1) & $(2)$ & $(3)$ & (4) \\
\hline \multicolumn{6}{|c|}{ B. Years of education $(25+)$} \\
\hline \multirow{4}{*}{ GCOV } & 1996 & 0.148 & 0.025 & 0.027 & 0.159 \\
\hline & 2001 & 0.120 & 0.065 & 0.028 & 0.141 \\
\hline & 2011 & 0.064 & 0.040 & 0.016 & 0.146 \\
\hline & $\Delta$ & - & + & - & - \\
\hline \multirow{4}{*}{ GGini } & 1996 & 0.048 & 0.112 & 0.010 & 0.069 \\
\hline & 2001 & 0.038 & 0.077 & 0.011 & 0.063 \\
\hline & 2011 & 0.021 & 0.055 & 0.006 & 0.041 \\
\hline & $\Delta$ & - & - & - & - \\
\hline \multirow{4}{*}{ GTheil } & 1996 & 0.043 & 0.037 & 0.001 & 0.039 \\
\hline & 2001 & 0.031 & 0.027 & 0.001 & 0.033 \\
\hline & 2011 & 0.011 & 0.010 & 0.000 & 0.014 \\
\hline & $\Delta$ & - & - & - & - \\
\hline \multirow{2}{*}{ Cross- } & 1996 & 0.512 & 0.211 & 0.502 & 0.501 \\
\hline & 2001 & 0.548 & 0.208 & 0.502 & 0.514 \\
\hline \multirow{2}{*}{ fractionalization } & 2011 & 0.577 & 0.210 & 0.502 & 0.537 \\
\hline & $\Delta$ & + & - & & + \\
\hline \multirow{2}{*}{ Cross- } & 1996 & 0.738 & 0.885 & 0.290 & 0.276 \\
\hline & 2001 & 0.560 & 0.885 & 0.289 & 0.266 \\
\hline \multirow{2}{*}{ cuttingness } & 2011 & 0.613 & 0.898 & 0.290 & 0.247 \\
\hline & $\Delta$ & - & + & & - \\
\hline
\end{tabular}

Source: Authors' calculations. $\Delta$ is change from 1996 to 2011 
Table 7: Aggregate measures of horizontal inequality

\begin{tabular}{|c|c|c|c|c|c|}
\hline & Year & Race & Language & Gender & Rural/Urban \\
\hline & & (1) & $(2)$ & $(3)$ & $(4)$ \\
\hline \multicolumn{6}{|c|}{ C. Years of education $(-15)$} \\
\hline \multirow{4}{*}{ GCOV } & 1996 & 0.037 & 0.008 & 0.042 & 0.056 \\
\hline & 2001 & 0.024 & 0.034 & 0.031 & 0.019 \\
\hline & 2011 & 0.021 & 0.001 & 0.016 & 0.009 \\
\hline & $\Delta$ & - & - & - & - \\
\hline \multirow{4}{*}{ GGini } & 1996 & 0.024 & 0.048 & 0.015 & 0.023 \\
\hline & 2001 & 0.016 & 0.028 & 0.011 & 0.008 \\
\hline & 2011 & 0.004 & 0.016 & 0.006 & 0.003 \\
\hline & $\Delta$ & - & - & - & - \\
\hline \multirow{4}{*}{ GTheil } & 1996 & 0.005 & 0.007 & 0.002 & 0.004 \\
\hline & 2001 & 0.002 & 0.002 & 0.001 & 0.000 \\
\hline & 2011 & 0.000 & 0.000 & 0.000 & 0.000 \\
\hline & $\Delta$ & - & - & - & - \\
\hline \multirow{2}{*}{ Cross- } & 1996 & 0.595 & 0.274 & 0.500 & 0.500 \\
\hline & 2001 & 0.616 & 0.304 & 0.500 & 0.500 \\
\hline \multirow{2}{*}{ fractionalization } & 2011 & 0.671 & 0.228 & 0.500 & 0.502 \\
\hline & $\Delta$ & + & - & & + \\
\hline \multirow{2}{*}{ Cross- } & 1996 & 0.708 & 0.882 & 0.293 & 0.287 \\
\hline & 2001 & 0.510 & 0.874 & 0.293 & 0.292 \\
\hline \multirow{2}{*}{ cuttingness } & 2011 & 0.573 & 0.888 & 0.293 & 0.291 \\
\hline & $\Delta$ & - & + & & + \\
\hline
\end{tabular}

Source: Authors' calculations. $\Delta$ is change from 1996 to 2011

Table 8: Gini inequality

\begin{tabular}{lccc}
\hline \hline & $\mathbf{1 9 9 6}$ & $\mathbf{2 0 0 1}$ & $\mathbf{2 0 1 1}$ \\
\hline Schooling (15+) & 0.33 & 0.32 & 0.24 \\
Schooling (25+) & 0.39 & 0.38 & 0.28 \\
Schooling (-15) & 0.54 & 0.62 & 0.46 \\
\hline
\end{tabular}

Source: Authors' calculations. 
Table 9: Vertical inequality: schooling. 15+

\begin{tabular}{ccccc}
\hline \hline \multirow{5}{*}{ Race } & & $\mathbf{1 9 9 6}$ & $\mathbf{2 0 0 1}$ & $\mathbf{2 0 1 1}$ \\
& Black & 0.37 & 0.35 & 0.25 \\
& Coloured & 0.26 & 0.24 & 0.20 \\
& Indian/Asian & 0.19 & 0.19 & 0.18 \\
& White & 0.12 & 0.14 & 0.14 \\
\hline \multirow{5}{*}{ Language } & IsiNdebele & 0.41 & 0.39 & 0.26 \\
& isiXhosa & 0.35 & 0.35 & 0.26 \\
& IsiZulu & 0.38 & 0.36 & 0.25 \\
& Sepedi & 0.38 & 0.36 & 0.25 \\
& Sesotho & 0.32 & 0.31 & 0.23 \\
& Setswana & 0.35 & 0.33 & 0.29 \\
& Siswati & 0.42 & 0.39 & 0.27 \\
& Tshivenda & 0.39 & 0.36 & 0.26 \\
& Xitsonga & 0.43 & 0.41 & 0.29 \\
& Afrikaans & 0.22 & 0.22 & 0.20 \\
& English & 0.15 & 0.16 & 0.16 \\
\hline \multirow{2}{*}{ Gender } & Female & 0.34 & 0.33 & 0.24 \\
& Male & 0.32 & 0.31 & 0.23 \\
\hline \multirow{2}{*}{ Rural/Urban } & Urban & 0.25 & 0.24 & 0.20 \\
& Rural & 0.43 & 0.43 & 0.31 \\
\hline
\end{tabular}

Source: Authors' calculations. 
Table 10: Ratio winner: schooling. (15+)

\begin{tabular}{|c|c|c|c|c|c|}
\hline \multicolumn{6}{|l|}{ Race } \\
\hline & GCOV & GGini & GTheil & $\mathrm{CC}$ & $\mathrm{CF}$ \\
\hline \multirow[t]{2}{*}{ Horizontal Inequality } & 0.19 & 0.44 & 0.98 & -0.14 & $0.48^{* *}$ \\
\hline & $(0.36)$ & $(0.81)$ & $(0.92)$ & $(0.12)$ & $(0.23)$ \\
\hline \multirow[t]{2}{*}{ Vertical Inequality } & 0.18 & 0.16 & 0.05 & 0.37 & $0.37^{*}$ \\
\hline & $(0.23)$ & $(0.24)$ & $(0.27)$ & $(0.23)$ & $(0.21)$ \\
\hline R-squared & 0.133 & 0.133 & 0.135 & 0.135 & 0.141 \\
\hline $\mathrm{N}$ & 702 & 702 & 702 & 702 & 702 \\
\hline \multicolumn{6}{|l|}{ Language } \\
\hline & GCOV & GGini & GTheil & $\mathrm{CC}$ & $\mathrm{CF}$ \\
\hline \multirow[t]{2}{*}{ Horizontal Inequality } & -0.47 & $-2.24^{* * *}$ & $-2.19^{* *}$ & $-0.85^{*}$ & 0.28 \\
\hline & $(0.34)$ & $(0.76)$ & $(1.09)$ & $(0.50)$ & $(0.19)$ \\
\hline \multirow[t]{2}{*}{ Vertical Inequality } & 0.32 & $0.51^{* *}$ & $0.52^{* *}$ & 0.10 & 0.20 \\
\hline & $(0.21)$ & $(0.22)$ & $(0.24)$ & $(0.21)$ & $(0.20)$ \\
\hline R-squared & 0.137 & 0.149 & 0.140 & 0.138 & 0.137 \\
\hline $\mathrm{N}$ & 702 & 702 & 702 & 702 & 702 \\
\hline \multicolumn{6}{|l|}{ Gender } \\
\hline & GCOV & GGini & GTheil & $\mathrm{CC}$ & $\mathrm{CF}$ \\
\hline \multirow[t]{2}{*}{ Horizontal Inequality } & $1.74^{*}$ & 3.23 & 4.53 & 0.67 & -0.66 \\
\hline & $(0.93)$ & $(2.74)$ & $(8.69)$ & $(1.48)$ & $(0.95)$ \\
\hline \multirow[t]{2}{*}{ Vertical Inequality } & 0.04 & 0.12 & 0.19 & 0.24 & 0.24 \\
\hline & $(0.22)$ & $(0.22)$ & $(0.22)$ & $(0.20)$ & $(0.20)$ \\
\hline R-squared & 0.139 & 0.135 & 0.133 & 0.133 & 0.134 \\
\hline $\mathrm{N}$ & 702 & 702 & 702 & 702 & 702 \\
\hline \multicolumn{6}{|l|}{ Urban/Rural } \\
\hline & GCOV & GGini & GTheil & $\mathrm{CC}$ & $\mathrm{CF}$ \\
\hline \multirow[t]{2}{*}{ Horizontal Inequality } & 0.05 & 0.09 & -0.60 & 0.23 & -0.12 \\
\hline & $(0.29)$ & $(0.99)$ & $(1.51)$ & $(0.19)$ & $(0.15)$ \\
\hline \multirow[t]{2}{*}{ Vertical Inequality } & 0.22 & 0.23 & 0.28 & 0.22 & 0.21 \\
\hline & $(0.21)$ & $(0.21)$ & $(0.22)$ & $(0.20)$ & $(0.20)$ \\
\hline R-squared & 0.133 & 0.133 & 0.133 & 0.135 & 0.134 \\
\hline $\mathrm{N}$ & 702 & 702 & 702 & 702 & 702 \\
\hline
\end{tabular}


Table 11: Ratio winner: schooling. (25+)

\begin{tabular}{|c|c|c|c|c|c|}
\hline \multicolumn{6}{|l|}{$\begin{array}{l}\text { Race } \\
\end{array}$} \\
\hline & GCOV & GGini & GTheil & $\mathrm{CC}$ & $\mathrm{CF}$ \\
\hline \multirow[t]{2}{*}{ Horizontal Inequality } & 0.02 & -0.05 & 0.37 & -0.13 & $0.48^{* *}$ \\
\hline & $(0.25)$ & $(0.64)$ & $(0.46)$ & $(0.12)$ & $(0.19)$ \\
\hline \multirow[t]{2}{*}{ Vertical Inequality } & 0.18 & 0.20 & 0.08 & 0.29 & $0.43^{* *}$ \\
\hline & $(0.19)$ & $(0.19)$ & $(0.21)$ & $(0.19)$ & $(0.19)$ \\
\hline R-squared & 0.133 & 0.133 & 0.134 & 0.135 & 0.144 \\
\hline $\mathrm{N}$ & 702 & 702 & 702 & 702 & 702 \\
\hline \multicolumn{6}{|l|}{ Language } \\
\hline & GCOV & GGini & GTheil & $\mathrm{CC}$ & $\mathrm{CF}$ \\
\hline \multirow[t]{2}{*}{ Horizontal Inequality } & $-0.47^{* *}$ & $-1.08^{* *}$ & -0.69 & $-0.89^{*}$ & $0.32^{*}$ \\
\hline & $(0.22)$ & $(0.52)$ & $(0.49)$ & $(0.50)$ & $(0.17)$ \\
\hline \multirow[t]{2}{*}{ Vertical Inequality } & $0.32^{*}$ & $0.35^{* *}$ & $0.34^{*}$ & 0.08 & 0.22 \\
\hline & $(0.17)$ & $(0.18)$ & $(0.19)$ & $(0.17)$ & $(0.16)$ \\
\hline R-squared & 0.141 & 0.141 & 0.137 & 0.139 & 0.139 \\
\hline $\mathrm{N}$ & 702 & 702 & 702 & 702 & 702 \\
\hline \multicolumn{6}{|l|}{ Gender } \\
\hline & GCOV & GGini & GTheil & $\mathrm{CC}$ & $\mathrm{CF}$ \\
\hline \multirow{2}{*}{ Horizontal Inequality } & 0.20 & 1.10 & 2.81 & 0.45 & -0.50 \\
\hline & $(0.61)$ & $(1.90)$ & $(4.37)$ & $(1.30)$ & $(0.86)$ \\
\hline \multirow{2}{*}{ Vertical Inequality } & 0.17 & 0.14 & 0.14 & 0.20 & 0.19 \\
\hline & $(0.18)$ & $(0.18)$ & $(0.18)$ & $(0.16)$ & $(0.16)$ \\
\hline R-squared & 0.133 & 0.133 & 0.134 & 0.133 & 0.133 \\
\hline $\mathrm{N}$ & 702 & 702 & 702 & 702 & 702 \\
\hline \multicolumn{6}{|l|}{ Urban/Rural } \\
\hline & GCOV & GGini & GTheil & $\mathrm{CC}$ & $\mathrm{CF}$ \\
\hline \multirow[t]{2}{*}{ Horizontal Inequality } & -0.01 & 0.00 & -0.14 & 0.23 & -0.06 \\
\hline & $(0.24)$ & $(0.72)$ & $(0.54)$ & $(0.19)$ & $(0.15)$ \\
\hline \multirow[t]{2}{*}{ Vertical Inequality } & 0.19 & 0.19 & 0.21 & 0.18 & 0.17 \\
\hline & $(0.17)$ & $(0.17)$ & $(0.17)$ & $(0.16)$ & $(0.17)$ \\
\hline R-squared & 0.133 & 0.133 & 0.133 & 0.136 & 0.133 \\
\hline $\mathrm{N}$ & 702 & 702 & 702 & 702 & 702 \\
\hline
\end{tabular}


Table 12: Ratio winner: schooling. (-15)

\begin{tabular}{|c|c|c|c|c|c|}
\hline \multicolumn{6}{|l|}{ Race } \\
\hline & GCOV & GGini & GTheil & $\mathrm{CC}$ & $\mathrm{CF}$ \\
\hline \multirow[t]{2}{*}{ Horizontal Inequality } & -0.12 & -0.68 & 0.84 & 0.02 & 0.30 \\
\hline & $(0.36)$ & $(0.95)$ & $(1.87)$ & $(0.10)$ & $(0.19)$ \\
\hline \multirow[t]{2}{*}{ Vertical Inequality } & $1.46^{* * *}$ & $1.48^{* * *}$ & $1.41^{* * *}$ & $1.45^{* * *}$ & $1.56^{* * *}$ \\
\hline & $(0.26)$ & $(0.26)$ & $(0.26)$ & $(0.26)$ & $(0.26)$ \\
\hline R-squared & 0.187 & 0.188 & 0.187 & 0.187 & 0.191 \\
\hline $\mathrm{N}$ & 702 & 702 & 702 & 702 & 702 \\
\hline \multicolumn{6}{|l|}{ Language } \\
\hline & GCOV & GGini & GTheil & $\mathrm{CC}$ & $\mathrm{CF}$ \\
\hline \multirow{2}{*}{ Horizontal Inequality } & -0.44 & -0.92 & -1.21 & $-1.06^{* *}$ & 0.21 \\
\hline & $(0.40)$ & $(0.86)$ & $(1.70)$ & $(0.51)$ & $(0.18)$ \\
\hline \multirow{2}{*}{ Vertical Inequality } & $1.47^{* * *}$ & $1.50^{* * *}$ & $1.49^{* * *}$ & $1.45^{* * *}$ & $1.48^{* * *}$ \\
\hline & $(0.26)$ & $(0.26)$ & $(0.26)$ & $(0.25)$ & $(0.26)$ \\
\hline R-squared & 0.189 & 0.189 & 0.188 & 0.194 & 0.189 \\
\hline $\mathrm{N}$ & 702 & 702 & 702 & 702 & 702 \\
\hline \multicolumn{6}{|l|}{ Gender } \\
\hline & GCOV & GGini & GTheil & $\mathrm{CC}$ & $\mathrm{CF}$ \\
\hline \multirow[t]{2}{*}{ Horizontal Inequality } & 0.37 & 0.97 & 5.57 & -2.49 & -1.42 \\
\hline & $(0.45)$ & $(1.28)$ & $(4.37)$ & $(1.63)$ & $(0.99)$ \\
\hline \multirow[t]{2}{*}{ Vertical Inequality } & $1.41^{* * *}$ & $1.41^{* * *}$ & $1.37^{* * *}$ & $1.55^{* * *}$ & $1.52^{* * *}$ \\
\hline & $(0.26)$ & $(0.26)$ & $(0.26)$ & $(0.26)$ & $(0.26)$ \\
\hline R-squared & 0.188 & 0.188 & 0.190 & 0.191 & 0.190 \\
\hline $\mathrm{N}$ & 702 & 702 & 702 & 702 & 702 \\
\hline \multicolumn{6}{|l|}{ Urban/Rural } \\
\hline & GCOV & GGini & GTheil & $\mathrm{CC}$ & $\mathrm{CF}$ \\
\hline \multirow[t]{2}{*}{ Horizontal Inequality } & $0.56^{*}$ & 1.56 & $4.28^{* *}$ & $0.30^{*}$ & -0.12 \\
\hline & $(0.29)$ & $(0.97)$ & $(1.95)$ & $(0.18)$ & $(0.14)$ \\
\hline \multirow[t]{2}{*}{ Vertical Inequality } & $1.38^{* * *}$ & $1.36^{* * *}$ & $1.34^{* * *}$ & $1.46^{* * *}$ & $1.40^{* * *}$ \\
\hline & $(0.26)$ & $(0.26)$ & $(0.26)$ & $(0.25)$ & $(0.26)$ \\
\hline R-squared & 0.193 & 0.191 & 0.195 & 0.192 & 0.188 \\
\hline $\mathrm{N}$ & 702 & 702 & 702 & 702 & 702 \\
\hline
\end{tabular}


Table 13: Winning margin: schooling. (15+)

\begin{tabular}{|c|c|c|c|c|c|}
\hline \multicolumn{6}{|l|}{ Race } \\
\hline & GCOV & GGini & GTheil & $\mathrm{CC}$ & $\mathrm{CF}$ \\
\hline \multirow[t]{2}{*}{ Horizontal Inequality } & 0.07 & -0.04 & 0.38 & 0.17 & 0.09 \\
\hline & $(0.39)$ & $(0.88)$ & $(1.00)$ & $(0.13)$ & $(0.25)$ \\
\hline \multirow[t]{2}{*}{ Vertical Inequality } & 0.23 & 0.26 & 0.18 & 0.09 & 0.28 \\
\hline & $(0.25)$ & $(0.26)$ & $(0.29)$ & $(0.25)$ & $(0.23)$ \\
\hline R-squared & 0.042 & 0.042 & 0.042 & 0.045 & 0.042 \\
\hline $\mathrm{N}$ & 702 & 702 & 702 & 702 & 702 \\
\hline \multicolumn{6}{|l|}{ Language } \\
\hline & GCOV & GGini & GTheil & $\mathrm{CC}$ & $\mathrm{CF}$ \\
\hline \multirow[t]{2}{*}{ Horizontal Inequality } & $-0.68^{*}$ & $-2.96^{* * *}$ & $-2.76^{* *}$ & -0.46 & 0.02 \\
\hline & $(0.37)$ & $(0.82)$ & $(1.18)$ & $(0.55)$ & $(0.21)$ \\
\hline \multirow[t]{2}{*}{ Vertical Inequality } & $0.38^{*}$ & $0.61^{* * *}$ & $0.62^{* *}$ & 0.19 & 0.25 \\
\hline & $(0.22)$ & $(0.23)$ & $(0.26)$ & $(0.23)$ & $(0.22)$ \\
\hline R-squared & 0.049 & 0.068 & 0.053 & 0.043 & 0.042 \\
\hline $\mathrm{N}$ & 702 & 702 & 702 & 702 & 702 \\
\hline \multicolumn{6}{|l|}{ Gender } \\
\hline & GCOV & GGini & GTheil & $\mathrm{CC}$ & $\mathrm{CF}$ \\
\hline \multirow[t]{2}{*}{ Horizontal Inequality } & $2.86^{* * *}$ & $6.35^{* *}$ & $16.95^{*}$ & 1.20 & -0.75 \\
\hline & $(1.01)$ & $(2.98)$ & $(9.45)$ & $(1.62)$ & $(1.03)$ \\
\hline \multirow[t]{2}{*}{ Vertical Inequality } & -0.06 & 0.02 & 0.08 & 0.26 & 0.26 \\
\hline & $(0.24)$ & $(0.24)$ & $(0.24)$ & $(0.22)$ & $(0.21)$ \\
\hline R-squared & 0.058 & 0.051 & 0.048 & 0.043 & 0.043 \\
\hline $\mathrm{N}$ & 702 & 702 & 702 & 702 & 702 \\
\hline \multicolumn{6}{|l|}{ Urban/Rural } \\
\hline & GCOV & GGini & GTheil & $\mathrm{CC}$ & $\mathrm{CF}$ \\
\hline \multirow[t]{2}{*}{ Horizontal Inequality } & 0.04 & 0.17 & 0.27 & 0.13 & -0.12 \\
\hline & $(0.32)$ & $(1.08)$ & $(1.65)$ & $(0.21)$ & $(0.16)$ \\
\hline \multirow[t]{2}{*}{ Vertical Inequality } & 0.24 & 0.24 & 0.24 & 0.25 & 0.23 \\
\hline & $(0.23)$ & $(0.23)$ & $(0.24)$ & $(0.22)$ & $(0.22)$ \\
\hline R-squared & 0.042 & 0.042 & 0.042 & 0.042 & 0.043 \\
\hline $\mathrm{N}$ & 702 & 702 & 702 & 702 & 702 \\
\hline
\end{tabular}


Table 14: Winning margin: schooling. (25+)

\begin{tabular}{|c|c|c|c|c|c|}
\hline \multicolumn{6}{|l|}{ 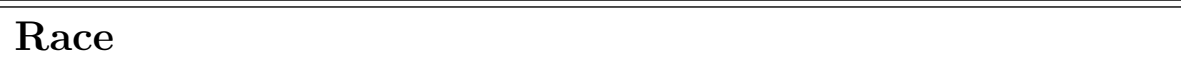 } \\
\hline & GCOV & GGini & GTheil & $\mathrm{CC}$ & $\mathrm{CF}$ \\
\hline \multirow[t]{2}{*}{ Horizontal Inequality } & -0.12 & -0.29 & 0.35 & 0.19 & 0.05 \\
\hline & $(0.27)$ & $(0.70)$ & $(0.50)$ & $(0.13)$ & $(0.21)$ \\
\hline \multirow[t]{2}{*}{ Vertical Inequality } & 0.22 & 0.21 & 0.07 & 0.02 & 0.19 \\
\hline & $(0.21)$ & $(0.20)$ & $(0.23)$ & $(0.20)$ & $(0.21)$ \\
\hline R-squared & 0.041 & 0.041 & 0.041 & 0.045 & 0.041 \\
\hline $\mathrm{N}$ & 702 & 702 & 702 & 702 & 702 \\
\hline \multicolumn{6}{|l|}{ Language } \\
\hline & GCOV & GGini & GTheil & $\mathrm{CC}$ & $\mathrm{CF}$ \\
\hline \multirow[t]{2}{*}{ Horizontal Inequality } & $-0.57^{* *}$ & $-1.45^{* *}$ & -0.59 & -0.52 & -0.03 \\
\hline & $(0.24)$ & $(0.57)$ & $(0.53)$ & $(0.54)$ & $(0.19)$ \\
\hline \multirow[t]{2}{*}{ Vertical Inequality } & $0.32^{*}$ & $0.38^{*}$ & 0.30 & 0.10 & 0.16 \\
\hline & $(0.19)$ & $(0.19)$ & $(0.21)$ & $(0.19)$ & $(0.18)$ \\
\hline R-squared & 0.052 & 0.054 & 0.043 & 0.042 & 0.041 \\
\hline $\mathrm{N}$ & 702 & 702 & 702 & 702 & 702 \\
\hline \multicolumn{6}{|l|}{ Gender } \\
\hline & GCOV & GGini & GTheil & $\mathrm{CC}$ & $\mathrm{CF}$ \\
\hline \multirow[t]{2}{*}{ Horizontal Inequality } & 0.40 & 2.65 & $7.95^{*}$ & 1.45 & -1.15 \\
\hline & $(0.67)$ & $(2.07)$ & $(4.76)$ & $(1.42)$ & $(0.94)$ \\
\hline \multirow[t]{2}{*}{ Vertical Inequality } & 0.12 & 0.04 & 0.02 & 0.19 & 0.16 \\
\hline & $(0.19)$ & $(0.20)$ & $(0.19)$ & $(0.18)$ & $(0.18)$ \\
\hline R-squared & 0.041 & 0.044 & 0.046 & 0.043 & 0.044 \\
\hline $\mathrm{N}$ & 702 & 702 & 702 & 702 & 702 \\
\hline \multicolumn{6}{|l|}{ Urban/Rural } \\
\hline & GCOV & GGini & GTheil & $\mathrm{CC}$ & $\mathrm{CF}$ \\
\hline \multirow[t]{2}{*}{ Horizontal Inequality } & 0.11 & 0.33 & 0.41 & 0.13 & -0.12 \\
\hline & $(0.26)$ & $(0.79)$ & $(0.59)$ & $(0.21)$ & $(0.16)$ \\
\hline \multirow[t]{2}{*}{ Vertical Inequality } & 0.14 & 0.14 & 0.12 & 0.16 & 0.12 \\
\hline & $(0.18)$ & $(0.18)$ & $(0.19)$ & $(0.18)$ & $(0.18)$ \\
\hline R-squared & 0.041 & 0.041 & 0.042 & 0.041 & 0.042 \\
\hline $\mathrm{N}$ & 702 & 702 & 702 & 702 & 702 \\
\hline
\end{tabular}


Table 15: Winning margin: schooling. (-15)

\begin{tabular}{|c|c|c|c|c|c|}
\hline \multicolumn{6}{|l|}{ Race } \\
\hline & GCOV & GGini & GTheil & $\mathrm{CC}$ & $\mathrm{CF}$ \\
\hline \multirow[t]{2}{*}{ Horizontal Inequality } & -0.45 & $-2.12^{* *}$ & -2.61 & $0.23^{* *}$ & -0.09 \\
\hline & $(0.40)$ & $(1.04)$ & $(2.05)$ & $(0.11)$ & $(0.21)$ \\
\hline \multirow[t]{2}{*}{ Vertical Inequality } & $1.43^{* * *}$ & $1.48^{* * *}$ & $1.47^{* * *}$ & $1.42^{* * *}$ & $1.34^{* * *}$ \\
\hline & $(0.28)$ & $(0.28)$ & $(0.29)$ & $(0.28)$ & $(0.29)$ \\
\hline R-squared & 0.089 & 0.095 & 0.090 & 0.096 & 0.087 \\
\hline $\mathrm{N}$ & 702 & 702 & 702 & 702 & 702 \\
\hline \multicolumn{6}{|l|}{ Language } \\
\hline & GCOV & GGini & GTheil & $\mathrm{CC}$ & $\mathrm{CF}$ \\
\hline \multirow[t]{2}{*}{ Horizontal Inequality } & $-0.77^{*}$ & $-1.86^{*}$ & -2.58 & -0.28 & 0.02 \\
\hline & $(0.44)$ & $(0.95)$ & $(1.87)$ & $(0.56)$ & $(0.20)$ \\
\hline \multirow{2}{*}{ Vertical Inequality } & $1.43^{* * *}$ & $1.50^{* * *}$ & $1.48^{* * *}$ & $1.38^{* * *}$ & $1.38 * * *$ \\
\hline & $(0.28)$ & $(0.29)$ & $(0.29)$ & $(0.28)$ & $(0.28)$ \\
\hline R-squared & 0.092 & 0.094 & 0.090 & 0.087 & 0.086 \\
\hline $\mathrm{N}$ & 702 & 702 & 702 & 702 & 702 \\
\hline \multicolumn{6}{|l|}{ Gender } \\
\hline & GCOV & GGini & GTheil & $\mathrm{CC}$ & $\mathrm{CF}$ \\
\hline \multirow{2}{*}{ Horizontal Inequality } & 0.52 & 1.40 & $8.12^{*}$ & -1.82 & -1.02 \\
\hline & $(0.49)$ & $(1.41)$ & $(4.80)$ & $(1.80)$ & $(1.09)$ \\
\hline \multirow[t]{2}{*}{ Vertical Inequality } & $1.33^{* * *}$ & $1.33^{* * *}$ & $1.27^{* * *}$ & $1.45^{* * *}$ & $1.43^{* * *}$ \\
\hline & $(0.28)$ & $(0.28)$ & $(0.29)$ & $(0.29)$ & $(0.29)$ \\
\hline R-squared & 0.089 & 0.088 & 0.092 & 0.088 & 0.088 \\
\hline $\mathrm{N}$ & 702 & 702 & 702 & 702 & 702 \\
\hline \multicolumn{6}{|l|}{ Urban/Rural } \\
\hline & GCOV & GGini & GTheil & $\mathrm{CC}$ & $\mathrm{CF}$ \\
\hline \multirow[t]{2}{*}{ Horizontal Inequality } & $0.59^{*}$ & $2.28^{* *}$ & $5.56^{* * *}$ & 0.23 & -0.23 \\
\hline & $(0.32)$ & $(1.06)$ & $(2.13)$ & $(0.19)$ & $(0.15)$ \\
\hline \multirow[t]{2}{*}{ Vertical Inequality } & $1.32^{* * *}$ & $1.25^{* * *}$ & $1.25^{* * *}$ & $1.39^{* * *}$ & $1.30^{* * *}$ \\
\hline & $(0.28)$ & $(0.28)$ & $(0.28)$ & $(0.28)$ & $(0.28)$ \\
\hline R-squared & 0.093 & 0.096 & 0.100 & 0.089 & 0.091 \\
\hline $\mathrm{N}$ & 702 & 702 & 702 & 702 & 702 \\
\hline
\end{tabular}


Figure 1: GCOV vs GGini - schooling (15+) and race - 2011

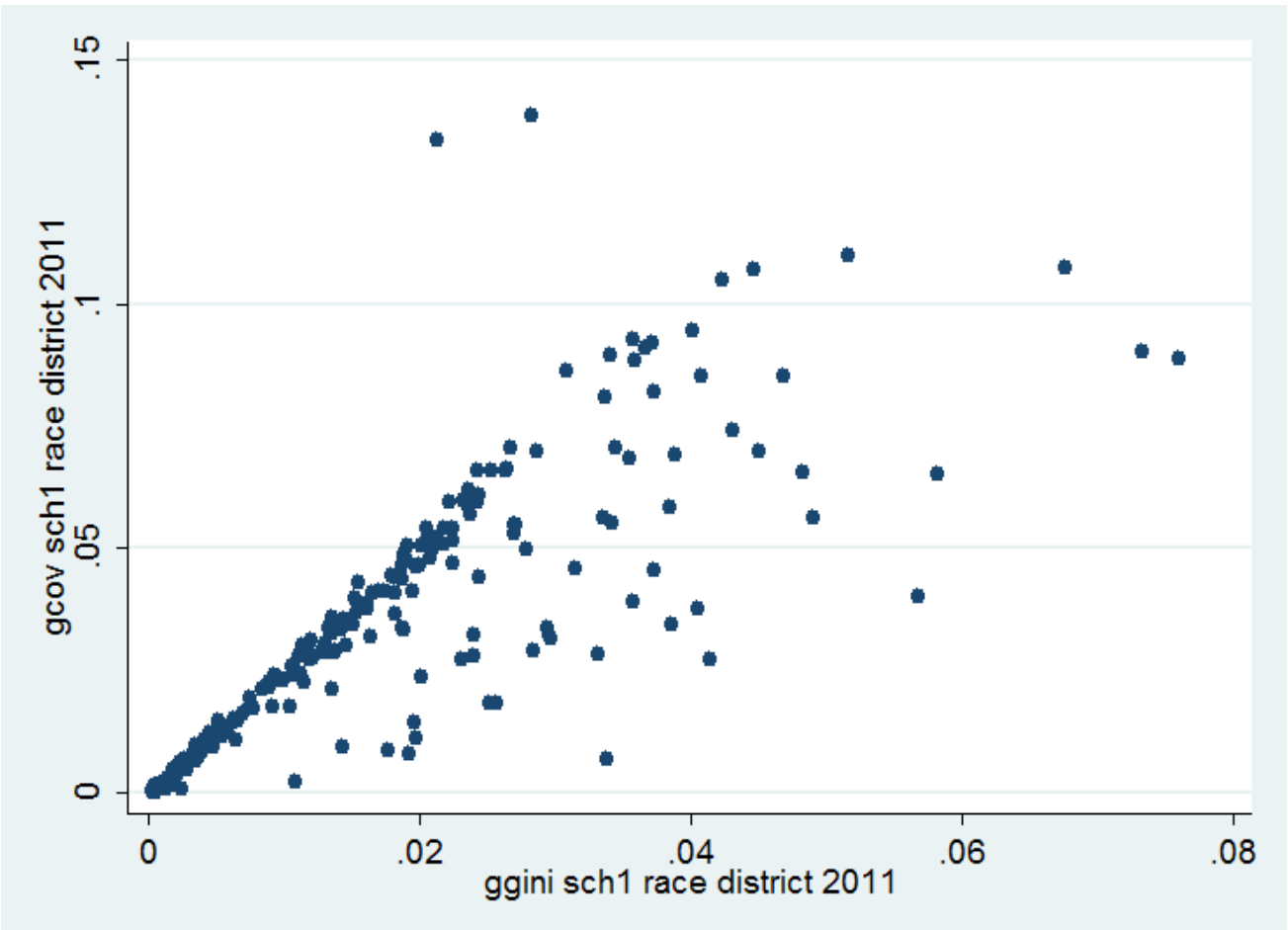

Source: Authors' calculations.

Figure 2: GTheil vs GGini - schooling (15+) and race - 2011

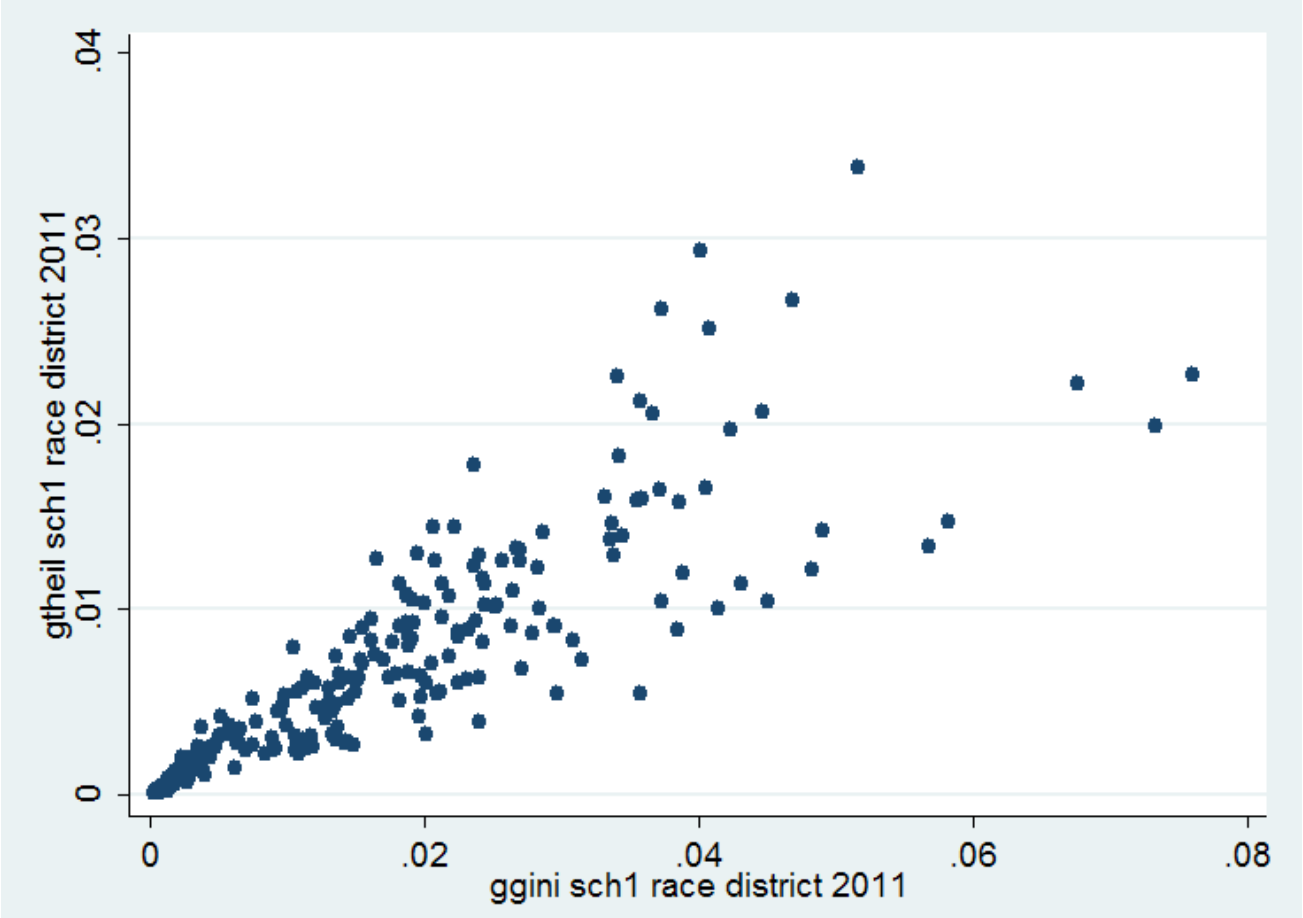

Source: Authors' calculations. 
Figure 3: Crossfractionalization and crosscuttingness - schooling (15+) and race - 2011

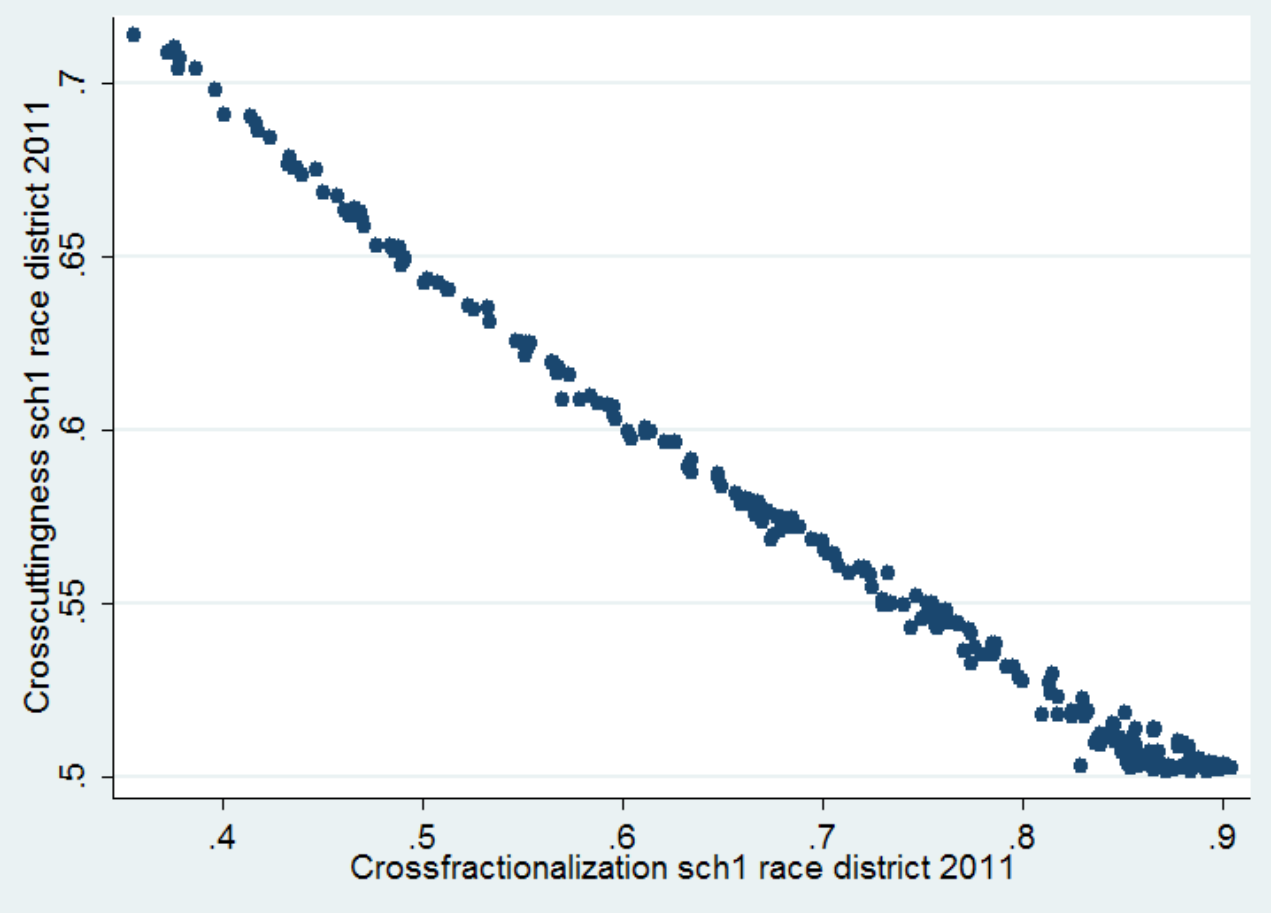

Source: Authors' calculations.

Figure 4: Crosscuttingness and Ggini - schooling (15+) and race - 2011



Source: Authors' calculations. 
Figure 5: GCOV schooling (15+) and race

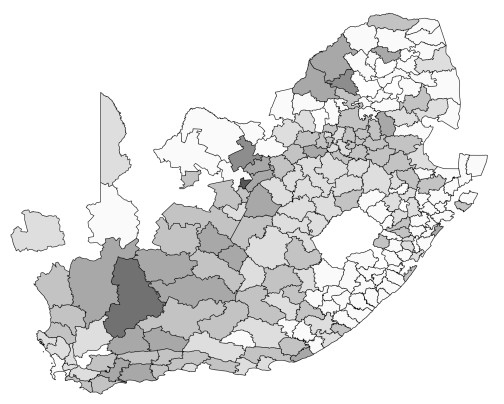

(a) 1996

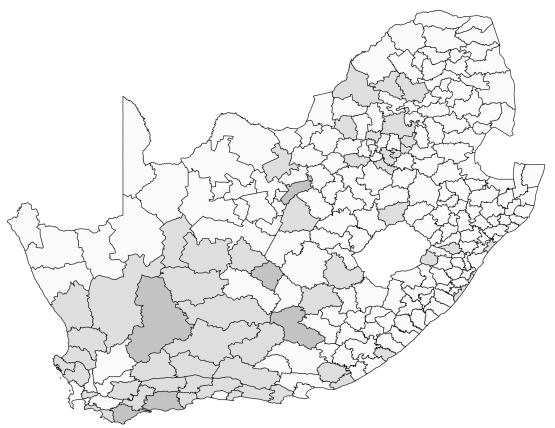

(c) 2011

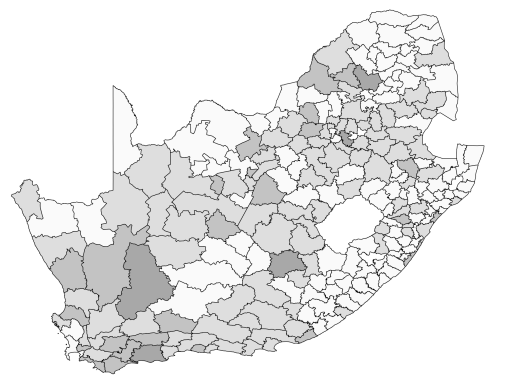

(b) 2001

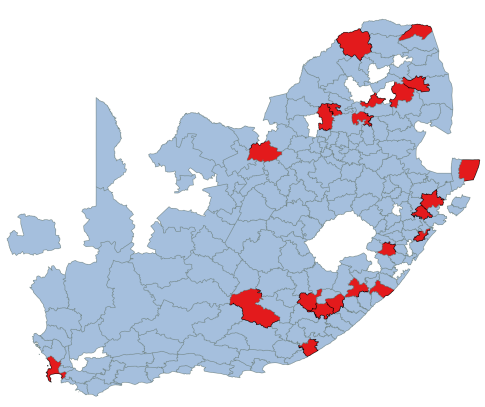

(d) Change

Source: Authors' calculations.

Figure 6: GCOV schooling (15+) and language

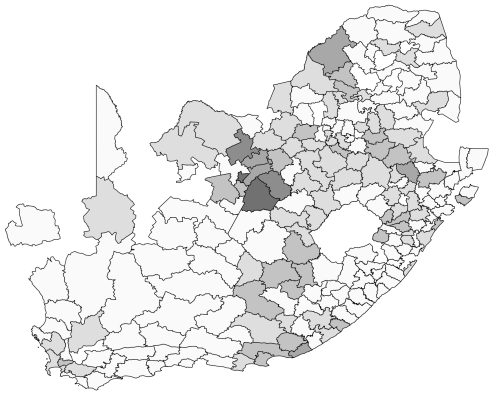

(a) 1996

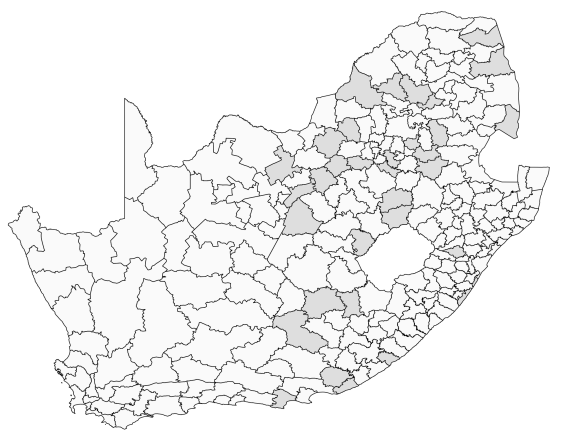

(c) 2011

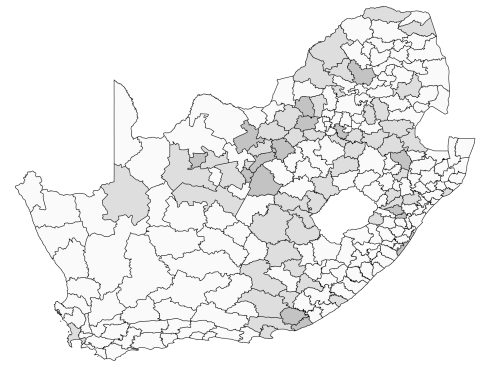

(b) 2001

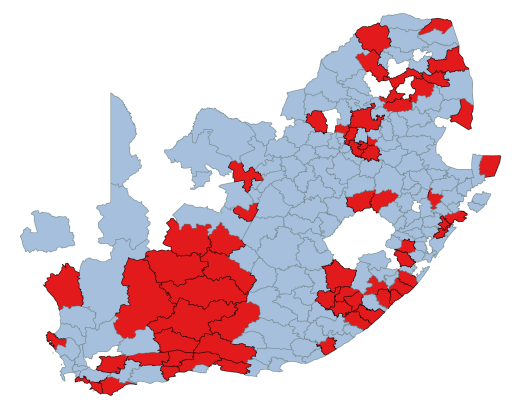

(d) Change

Source: Authors' calculations. 
Figure 7: GCOV schooling (15+) and gender

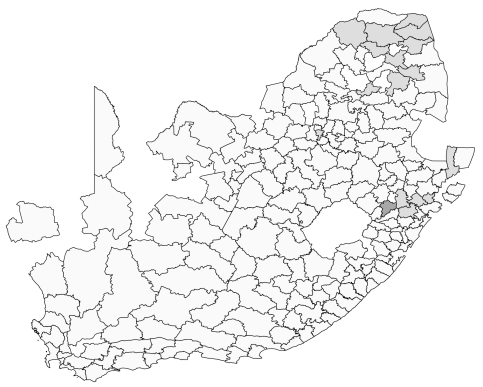

(a) 1996

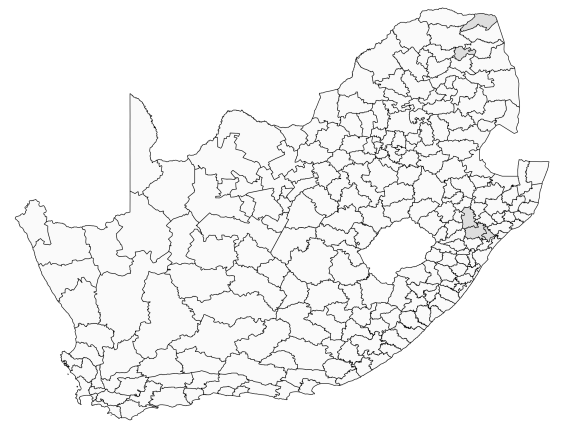

(c) 2011

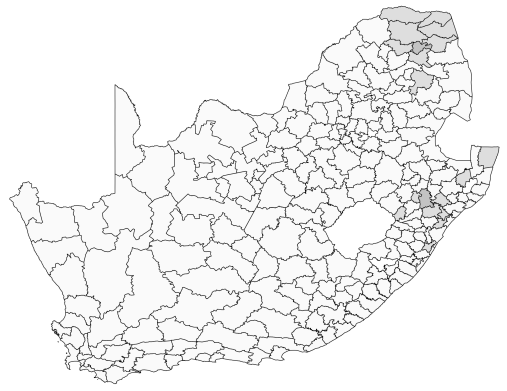

(b) 2001

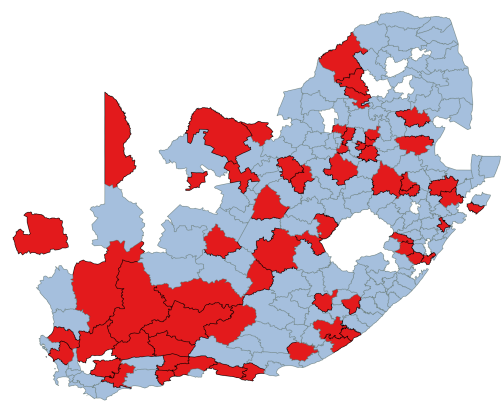

(d) Change

Source: Authors' calculations.

Figure 8: GCOV schooling (15+) and urban

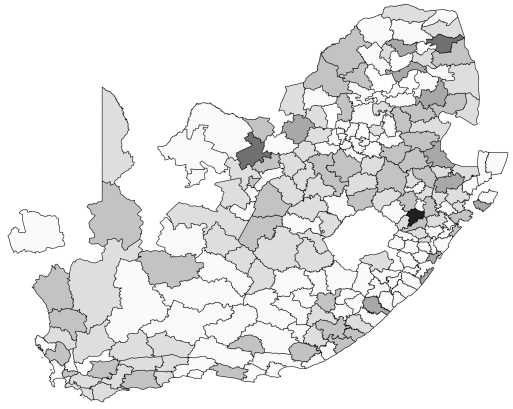

(a) 1996

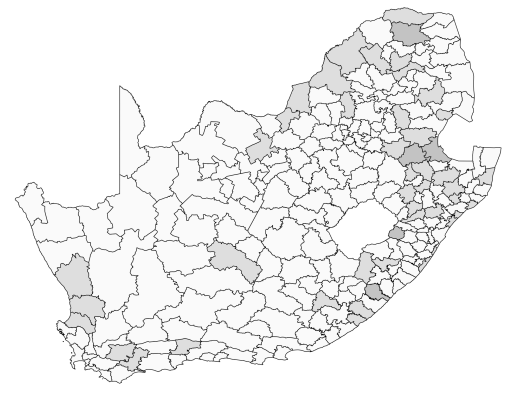

(c) 2011



(b) 2001

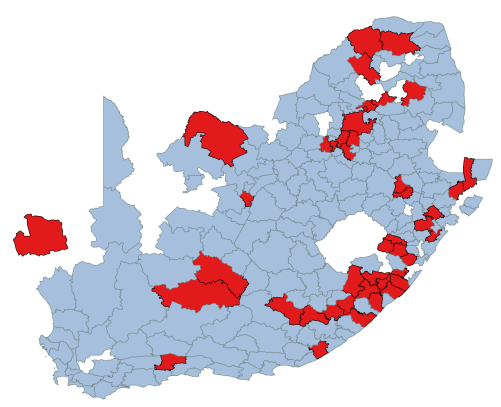

(d) Change

Source: Authors' calculations. 


\section{Appendix}

\section{A.1 Unmatched municipalities}

\section{A.1.1 1996}

Breede Valley, Bitou, Ga-Segonyane, Richtersveld, Kamiesberg, Khai-Ma, Khara Hais, Kheis, Tsantsabane, Kgatelopele, Umzumbe, Ezingoleni, uMhlathuze, uMdoni, Mkham-

bathini, Indaka, The Big 5 False Bay, Hlabisa, Ntambanana, Mandeni, Greater Kokstad, Rustenburg, Mafikeng, Umjindi, Greater Letaba, Polokwane, Mookgopong, Makhuduthamaga, Fetakgomo.

\section{A.1.2 2001}

Lesedi, Hlabisa, Umzimvubu. 


\section{A.2 Vertical inequality}

Table A2.1: Vertical inequality: schooling. (25+)

\begin{tabular}{ccccc}
\hline \hline & & $\mathbf{1 9 9 6}$ & $\mathbf{2 0 0 1}$ & $\mathbf{2 0 1 1}$ \\
\hline \multirow{4}{*}{ Race } & Black & 0.44 & 0.43 & 0.30 \\
& Indian/Asian & 0.22 & 0.21 & 0.16 \\
White & 0.12 & 0.14 & 0.14 \\
\hline \multirow{4}{*}{ Language } & IsiNdebele & 0.52 & 0.48 & 0.31 \\
& isiXhosa & 0.41 & 0.42 & 0.30 \\
& IsiZulu & 0.45 & 0.43 & 0.31 \\
Sepedi & 0.48 & 0.45 & 0.31 \\
Sesotho & 0.37 & 0.36 & 0.27 \\
& Siswati & 0.53 & 0.49 & 0.30 \\
& Tshivenda & 0.51 & 0.46 & 0.31 \\
Xitsonga & 0.54 & 0.50 & 0.35 \\
Afrikaans & 0.24 & 0.25 & 0.21 \\
English & 0.16 & 0.17 & 0.17 \\
\hline
\end{tabular}

Source: Authors' calculations. 
Table A2.2: Vertical inequality: schooling. (-15)

\begin{tabular}{ccccc}
\hline \hline \multirow{4}{*}{ Race } & & $\mathbf{1 9 9 6}$ & $\mathbf{2 0 0 1}$ & $\mathbf{2 0 1 1}$ \\
\hline \multirow{6}{*}{ Language } & Black & 0.44 & 0.43 & 0.30 \\
& Indian/Asian & 0.22 & 0.21 & 0.16 \\
& White & 0.12 & 0.14 & 0.14 \\
\hline & IsiNdebele & 0.51 & 0.62 & 0.46 \\
& isiXhosa & 0.60 & 0.62 & 0.47 \\
& IsiZulu & 0.54 & 0.63 & 0.45 \\
& Sepedi & 0.53 & 0.61 & 0.45 \\
& Sesotho & 0.53 & 0.62 & 0.46 \\
& Setswana & 0.54 & 0.63 & 0.46 \\
& Siswati & 0.55 & 0.63 & 0.44 \\
& Tshivenda & 0.54 & 0.60 & 0.46 \\
& Xitsonga & 0.53 & 0.62 & 0.54 \\
& Afrikaans & 0.49 & 0.60 & 0.46 \\
& English & 0.45 & 0.60 & 0.45 \\
\hline
\end{tabular}

Source: Authors' calculations. 
A.3 Full regression results 
Table A3.1: Ratio winner: schooling. (15+)

\begin{tabular}{|c|c|c|c|c|c|}
\hline \multicolumn{6}{|l|}{ Race } \\
\hline & GCOV & GGini & GTheil & $\mathrm{CC}$ & $\mathrm{CF}$ \\
\hline \multirow[t]{2}{*}{ Horizontal Inequality } & 0.19 & 0.44 & 0.98 & -0.14 & $0.48^{* *}$ \\
\hline & $(0.36)$ & $(0.81)$ & $(0.92)$ & $(0.12)$ & $(0.23)$ \\
\hline \multirow[t]{2}{*}{ Vertical Inequality } & 0.18 & 0.16 & 0.05 & 0.37 & $0.37^{*}$ \\
\hline & $(0.23)$ & $(0.24)$ & $(0.27)$ & $(0.23)$ & $(0.21)$ \\
\hline \multirow[t]{2}{*}{ Ratio earn above minimum category } & $0.42 * * *$ & $0.42^{* * *}$ & $0.41 * * *$ & $0.45 * * *$ & $0.40^{* * *}$ \\
\hline & $(0.12)$ & $(0.12)$ & $(0.12)$ & $(0.13)$ & $(0.12)$ \\
\hline \multirow[t]{2}{*}{ Fraction electricity } & $-0.19^{* *}$ & $-0.18^{* *}$ & $-0.18^{* *}$ & $-0.18^{* *}$ & $-0.17 * *$ \\
\hline & $(0.08)$ & $(0.08)$ & $(0.08)$ & $(0.08)$ & $(0.08)$ \\
\hline \multirow{2}{*}{ Fraction female } & $0.77 * * *$ & $0.78^{* * *}$ & $0.84^{* * *}$ & $0.78 * * *$ & 0.21 \\
\hline & $(0.26)$ & $(0.26)$ & $(0.27)$ & $(0.26)$ & $(0.36)$ \\
\hline \multirow[t]{2}{*}{ Fraction black } & $-0.25^{*}$ & $-0.24^{*}$ & $-0.23^{*}$ & $-0.28 * *$ & $-0.42 * * *$ \\
\hline & $(0.13)$ & $(0.13)$ & $(0.13)$ & $(0.13)$ & $(0.14)$ \\
\hline \multirow[t]{2}{*}{ Fraction employed } & -0.24 & -0.26 & -0.29 & -0.05 & -0.08 \\
\hline & $(0.26)$ & $(0.28)$ & $(0.26)$ & $(0.27)$ & $(0.25)$ \\
\hline R-squared & 0.133 & 0.133 & 0.135 & 0.135 & 0.141 \\
\hline $\mathrm{N}$ & 702 & 702 & 702 & 702 & 702 \\
\hline \multicolumn{6}{|l|}{ Language } \\
\hline \multirow{3}{*}{ Horizontal Inequality } & GCOV & GGini & GTheil & $\mathrm{CC}$ & $\mathrm{CF}$ \\
\hline & -0.47 & $-2.24^{* * *}$ & $-2.19^{* *}$ & $-0.85^{*}$ & 0.28 \\
\hline & $(0.34)$ & $(0.76)$ & $(1.09)$ & $(0.50)$ & $(0.19)$ \\
\hline Vertical Inequality & 0.32 & $0.51^{* *}$ & $0.52^{* *}$ & 0.10 & 0.20 \\
\hline & $(0.21)$ & $(0.22)$ & $(0.24)$ & $(0.21)$ & $(0.20)$ \\
\hline Ratio earn above minimum category & $0.42 * * *$ & $0.46^{* * *}$ & $0.46^{* * *}$ & $0.46^{* * *}$ & $0.41^{* * *}$ \\
\hline & $(0.12)$ & $(0.12)$ & $(0.12)$ & $(0.13)$ & $(0.12)$ \\
\hline Fraction electricity & $-0.19^{* *}$ & $-0.21 * * *$ & $-0.20 * * *$ & $-0.19^{* *}$ & $-0.18^{* *}$ \\
\hline & $(0.08)$ & $(0.08)$ & $(0.08)$ & $(0.08)$ & $(0.08)$ \\
\hline Fraction female & $0.69 * * *$ & $0.54^{* *}$ & $0.57 * *$ & $1.75^{* * *}$ & 0.36 \\
\hline & $(0.26)$ & $(0.27)$ & $(0.27)$ & $(0.64)$ & $(0.37)$ \\
\hline Fraction black & $-0.27 * *$ & $-0.27 * *$ & $-0.29 * *$ & -0.17 & $-0.24^{*}$ \\
\hline & $(0.12)$ & $(0.12)$ & $(0.12)$ & $(0.14)$ & $(0.13)$ \\
\hline Fraction employed & -0.07 & 0.19 & 0.01 & 0.24 & -0.09 \\
\hline & $(0.26)$ & $(0.27)$ & $(0.26)$ & $(0.35)$ & $(0.25)$ \\
\hline R-squared & 0.137 & 0.149 & 0.140 & 0.138 & 0.137 \\
\hline $\mathrm{N}$ & 702 & 702 & 702 & 702 & 702 \\
\hline Gender & & & & & \\
\hline & GCOV & GGini & GTheil & $\mathrm{CC}$ & $\mathrm{CF}$ \\
\hline Horizontal Inequality & $1.74^{*}$ & 3.23 & 4.53 & 0.67 & -0.66 \\
\hline & $(0.93)$ & $(2.74)$ & $(8.69)$ & $(1.48)$ & $(0.95)$ \\
\hline Vertical Inequality & 0.04 & 0.12 & 0.19 & 0.24 & 0.24 \\
\hline & $(0.22)$ & $(0.22)$ & $(0.22)$ & $(0.20)$ & $(0.20)$ \\
\hline Ratio earn above minimum category & $0.41 * * *$ & $0.42^{* * *}$ & $0.42^{* * *}$ & $0.42^{* * *}$ & $0.44^{* * *}$ \\
\hline & $(0.12)$ & $(0.12)$ & $(0.12)$ & $(0.12)$ & $(0.12)$ \\
\hline Fraction electricity & $-0.18^{* *}$ & $-0.19 * *$ & $-0.19 * *$ & $-0.18^{* *}$ & $-0.19 * *$ \\
\hline & $(0.08)$ & $(0.08)$ & $(0.08)$ & $(0.08)$ & $(0.08)$ \\
\hline Fraction female & $0.79 * * *$ & $0.77 * * *$ & $0.77^{* * *}$ & 0.44 & 1.28 \\
\hline & $(0.26)$ & $(0.26)$ & $(0.26)$ & $(0.74)$ & $(0.80)$ \\
\hline Fraction black & $-0.27 * *$ & $-0.27^{* *}$ & $-0.26^{* *}$ & $-0.27 * *$ & $-0.23^{*}$ \\
\hline & $(0.12)$ & $(0.12)$ & $(0.12)$ & $(0.13)$ & $(0.13)$ \\
\hline Fraction employed & -0.11 & -0.13 & -0.16 & -0.29 & -0.03 \\
\hline & $(0.25)$ & $(0.25)$ & $(0.25)$ & $(0.33)$ & $(0.33)$ \\
\hline R-squared & 0.139 & 0.135 & 0.133 & 0.133 & 0.134 \\
\hline $\mathrm{N}$ & 702 & 702 & 702 & 702 & 702 \\
\hline Urban/Rural & & & & & \\
\hline & GCOV & GGini & GTheil & $\mathrm{CC}$ & $\mathrm{CF}$ \\
\hline Horizontal Inequality & 0.05 & 0.09 & -0.60 & 0.23 & -0.12 \\
\hline & $(0.29)$ & $(0.99)$ & $(1.51)$ & $(0.19)$ & $(0.15)$ \\
\hline Vertical Inequality & 0.22 & 0.23 & 0.28 & 0.22 & 0.21 \\
\hline & $(0.21)$ & $(0.21)$ & $(0.22)$ & $(0.20)$ & $(0.20)$ \\
\hline Ratio earn above minimum category & $0.43^{* * *}$ & $0.43^{* * *}$ & $0.43^{* * *}$ & $0.43^{* * *}$ & $0.44^{* * *}$ \\
\hline & $(0.12)$ & $(0.12)$ & $(0.12)$ & $(0.12)$ & $(0.12)$ \\
\hline Fraction electricity & $-0.19 * *$ & $-0.19 * *$ & $-0.19 * *$ & $-0.18^{* *}$ & $-0.19^{* *}$ \\
\hline & $(0.08)$ & $(0.08)$ & $(0.08)$ & $(0.08)$ & $(0.08)$ \\
\hline Fraction female & $0.76^{* * *}$ & $0.76^{* * *}$ & $0.73^{* * *}$ & $0.78^{* * *}$ & $0.95^{* * *}$ \\
\hline & $(0.27)$ & $(0.27)$ & $(0.27)$ & $(0.26)$ & $(0.35)$ \\
\hline Fraction black & $-0.26 * *$ & $-0.26 * *$ & $-0.26^{* *}$ & $-0.27 * *$ & $-0.26^{* *}$ \\
\hline & $(0.12)$ & $(0.12)$ & $(0.12)$ & $(0.12)$ & $(0.12)$ \\
\hline Fraction employed & -0.20 & -0.19 & -0.16 & -0.35 & -0.24 \\
\hline & $(0.26)$ & $(0.27)$ & $(0.25)$ & $(0.28)$ & $(0.25)$ \\
\hline R-squared & 0.133 & 0.133 & 0.133 & 0.135 & 0.134 \\
\hline $\mathrm{N}$ & 702 & 702 & 702 & 702 & 702 \\
\hline
\end{tabular}


Table A3.2: Ratio winner: schooling. $(25+)$

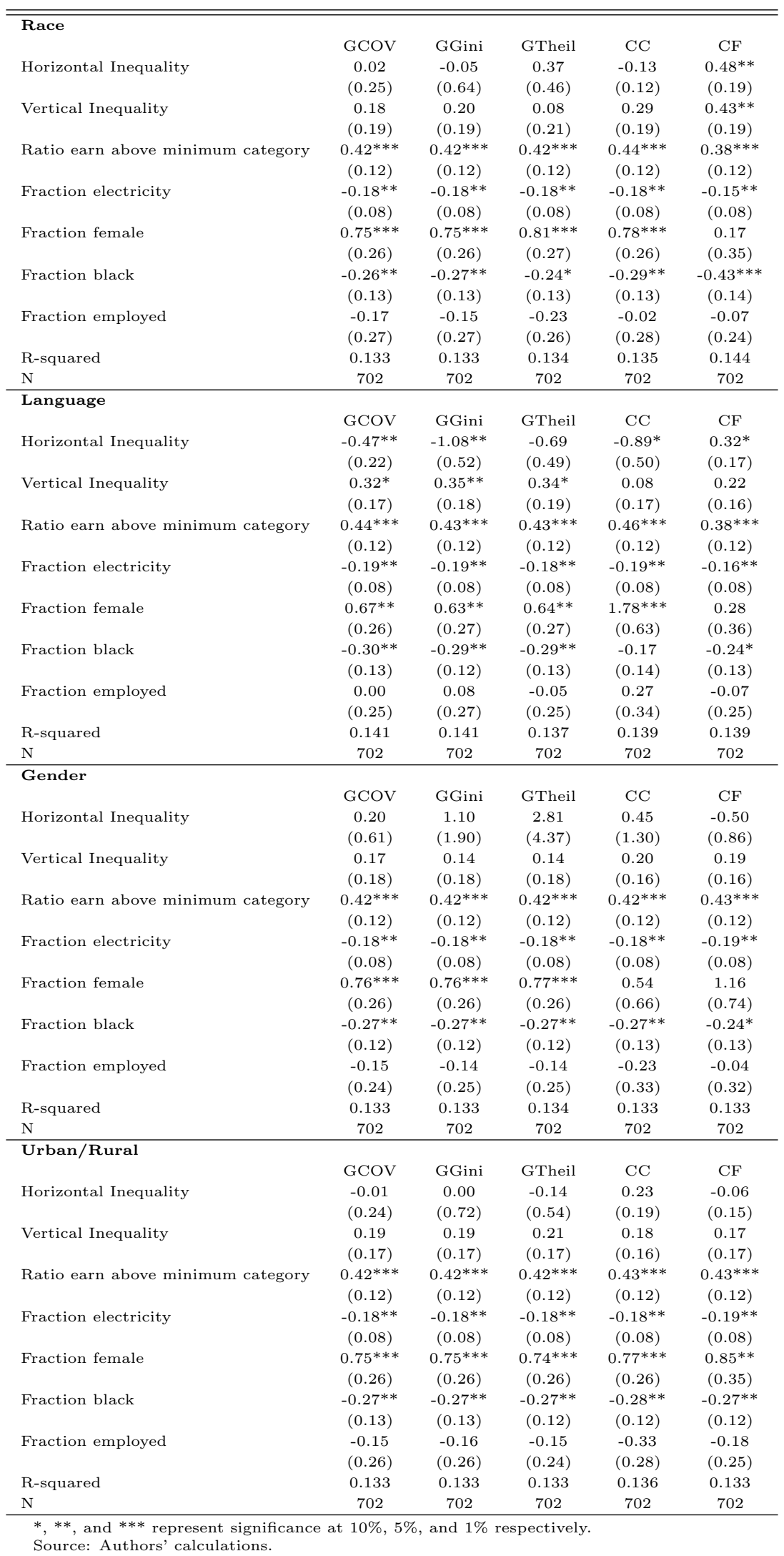


Table A3.3: Ratio winner: schooling. (-15)

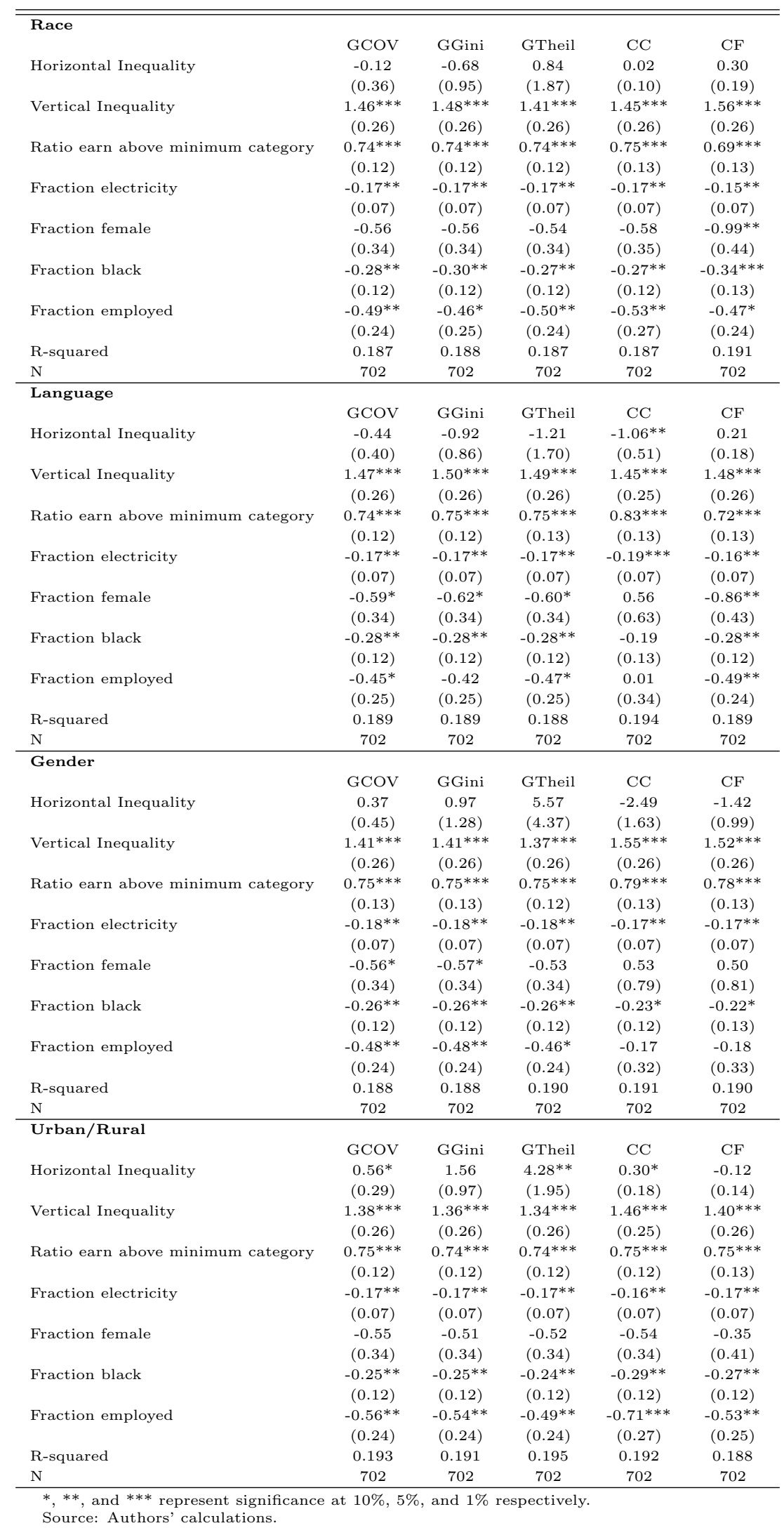


Table A3.4: Winning margin: schooling. (15+)

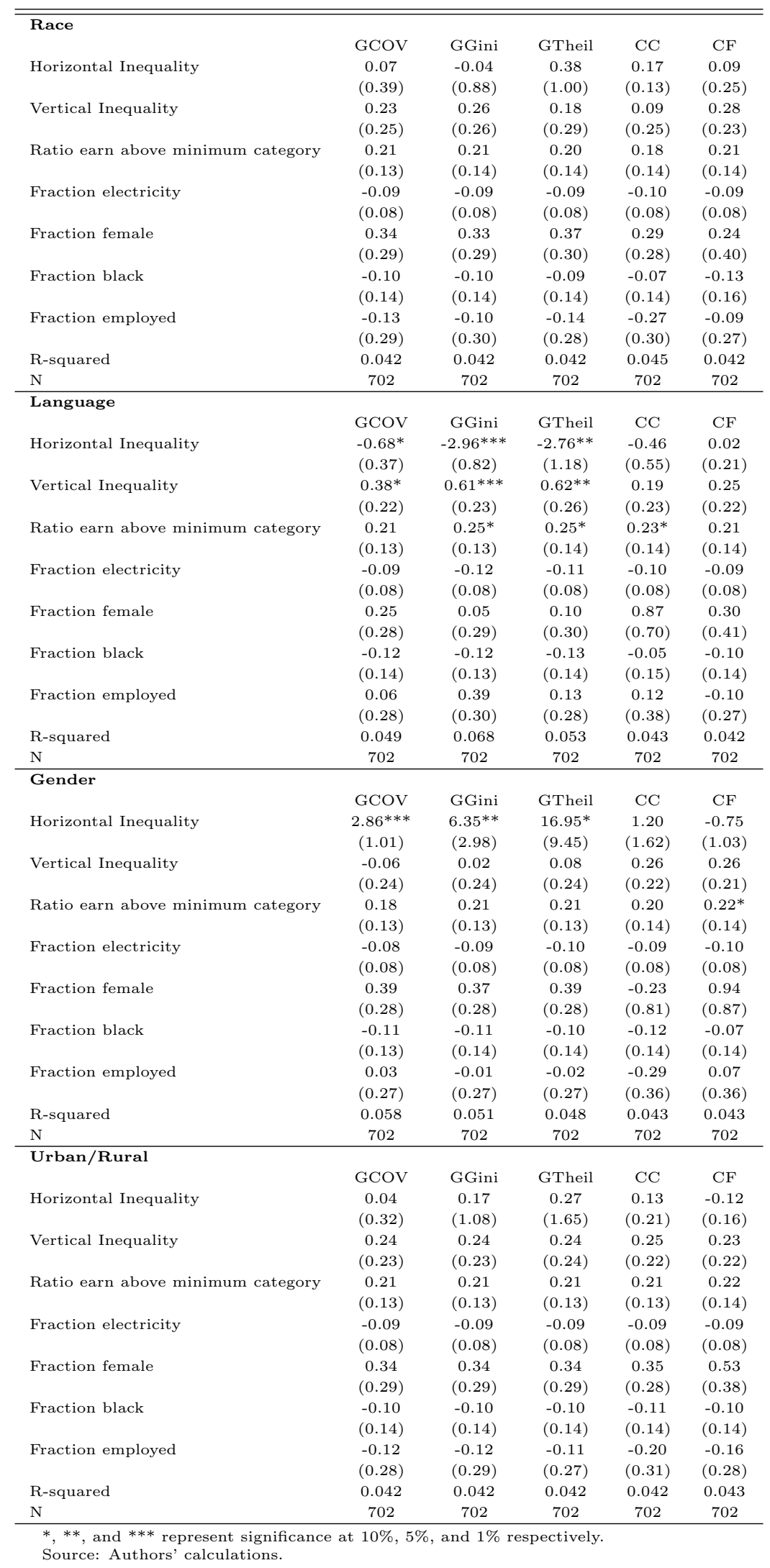


Table A3.5: Winning margin: schooling. (25+)




Table A3.6: Winning margin: schooling. (-15)

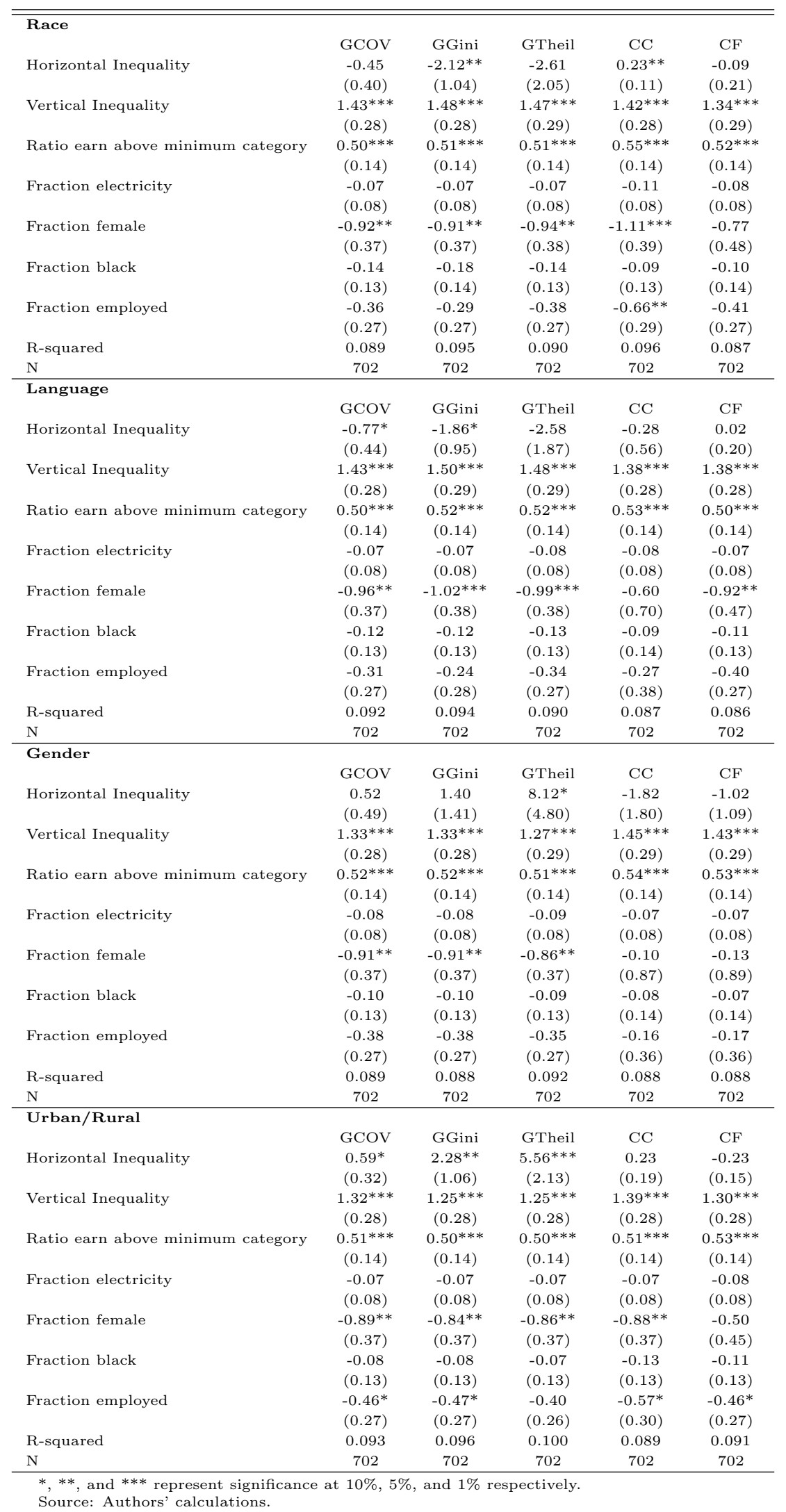

